\title{
Why do corporate cash holdings differ within reunified Germany?
}

\author{
Alexander Kupfer ${ }^{1}$ (D) Julia Oberndorfer ${ }^{2}$. Felix Kunz ${ }^{2}$
}

Accepted: 21 June 2021 / Published online: 23 July 2021

(c) The Author(s) 2021, corrected publication 2022

\begin{abstract}
This study examines German firms' managerial decision-making from the perspective of corporate cash holdings. An econometric analysis of 89,018 firm-year observations for 2004-2016 shows that East German firms hold significantly more cash than their West German counterparts. It is further demonstrated that no reasonable hypotheses (i.e. structural differences, access to financing, and historical differences) can explain East German firms' higher cash holdings. Instead, the difference in cash holdings is only relevant for small- and medium-sized enterprises (SMEs). Additionally, East German SMEs adjust excess cash more slowly than West German SMEs. These findings are consistent with the hypothesis that cultural attributes influence managerial decision-making and imply that the norms and values of the former German Democratic Republic persist.
\end{abstract}

Keywords Managerial decision-making $\cdot$ Corporate cash holdings $\cdot$ Speed of adjustment $\cdot \mathrm{SME} \cdot$ Cultural attributes $\cdot$ Germany

JEL Classification $\mathrm{G} 30 \cdot \mathrm{G} 32 \cdot \mathrm{M} 14 \cdot \mathrm{Z} 1$

\section{Introduction}

The German reunification in 1990 caused an unexpected and rapid change in the political system of the former socialist German Democratic Republic (GDR). ${ }^{1}$ While some studies estimated the transition to the West German system to be

\footnotetext{
1 For the sake of readability, we refer to states of the former GDR as East Germany and the 'old' states of the Federal Republic of Germany as West Germany throughout the paper.

Alexander Kupfer

alexander.kupfer@uibk.ac.at

1 Department of Information Systems, Production and Logistics Management and Digital Science Center, University of Innsbruck, Innsbruck, Austria

2 Department of Banking and Finance, University of Innsbruck, Innsbruck, Austria
} 
completed within 5 to 15 years (Beirat des Bundeswirtschaftsministeriums 1991; Dornbusch and Wolf 1994), more recent research, however, posits that norms and values can persist across generations (Necker and Voskort 2014; Wyrwich 2015). Consequently, it is unsurprising that many studies use the reunification of Germany as a quasi-natural experiment to analyse the impact of exposure to the former GDR's norms and values. Differences have been observed, for instance, in the labour market (Fuchs-Schündeln and Izem 2012; Snower and Merkl 2006; Uhlig 2006) or in household consumption and savings (Bursztyn and Cantoni 2016; Friehe and Mechtel 2014; Fuchs-Schündeln 2008). Furthermore, the preference for state interventions (Alesina and Fuchs-Schündeln 2007), the degree of solidarity (Brosig-Koch et al. 2011), and the level of trust and values (Heineck and Süssmuth 2013; Necker and Voskort 2014; Rainer and Siedler 2009) vary between East and West Germany, indicating a persistence of pre-existing norms and values.

Expanding the literature on observed differences in entrepreneurial activity (Bauernschuster et al. 2012; Fritsch et al. 2015; Runst 2013; Wyrwich 2013), we study a subsample of the East and West German population comprising individuals who decided to be entrepreneurs or managers. ${ }^{2}$ Thus, this study analyses managerial decision-making through the lens of corporate cash holdings, which reflects an important corporate finance decision independent of firm size. Our dataset ranges from 2004 to 2016 and contains 89,018 firm-year observations from 14,823 firms. Starting with an exploratory analysis, we observe statistically significant and robust differences in cash holdings between East and West German firms; specifically, East German firms have significantly higher cash levels than their West German counterparts.

We test several reasonable hypotheses that may potentially explain the higher cash holdings of East German firms. First, we exclude the possibility of structural differences in our sample by matching East German firms with West German firms based on firm characteristics and geographical proximity. Second, we control for different access to financing by considering different levels of external finance dependency, financial constraints, differences in bank concentration, and urbanisation effects. Third, we also address the possibility of historical differences by excluding firms founded before 1990 and by controlling for historical entrepreneurial roots. However, none of these specifications explain the significantly higher cash holdings of the East German firms.

The differences observed between East and West Germany in various situations, however, might also make a case for our analysis of managerial decision-making. In fact, Chen et al. (2015) observe that corporate cash holdings are influenced by cultural attributes and are higher in countries that are more collectivistic, whereas they are lower in the more individualistic countries, which is supported by our observation of higher cash holdings in East German firms. Therefore, we present two additional tests for the hypothesis of differences in cultural attributes between East and West German managerial decision-making. On the one hand, we separately compare

\footnotetext{
${ }^{2}$ For the ease of the readers, we use 'managers' throughout the paper even though our dataset mainly comprises micro-, small-, and medium-sized firms.
} 
East and West German firms for different size classes and observe that while there is no significant difference in cash holdings for large firms, it exists for medium-, small-, and micro-sized firms. This result is consistent with the hypothesis that the smaller a firm, the fewer the individuals involved in decision-making and the lower the probability that cultural attributes are diversified. On the other hand, we also analyse the dynamic adjustment of cash holdings and find that if firms hold more cash than their target level, East German firms adjust the excess cash more slowly than their West German counterparts. However, as information about the managers' origin and their individual cultural attributes is unavailable for us, we cannot conclude that the cultural differences of East German firm managers are the reason for this observation. In general, however, our results are consistent with the hypothesis of different cultural attributes, implying the persistence of the former GDR's norms and values.

Our study makes a two-fold contribution to the literature. First, we extend the existing research on the differences between East and West Germany with respect to managerial decision-making by examining accounting data. The significantly different levels of cash holdings observed between East and West German firms, however, call for further survey-based research to examine the existence of cultural attribute differences. Second, we add to a recently growing body of finance research that analyses the effect of cultural attributes on corporate finance policy.

The remainder of the paper is structured as follows: Sect. 2 outlines the German reunification as our research environment. Section 3 provides an overview of our dataset, the model specification, and the results of our exploratory baseline regression. In Sect. 4, we test potential explanations about different levels of cash holdings. In Sect. 5, we demonstrate that our results are consistent with the hypothesis of differences in cultural attributes between East and West German managerial decision-making. Finally, in Sect. 6 we present our conclusions.

\section{Research environment: Germany's reunification}

The history of Germany and its reunification in 1990 is of special academic interest because it represents a proxy for the transformation process of all former socialist countries of the former Eastern bloc. Early studies in the mid-nineties estimated the complete transition process to take between 5 years and up to a generation (Barro 1991; Beirat des Bundeswirtschaftsministeriums 1991; Dornbusch and Wolf 1994). Meanwhile, a plethora of studies have examined whether differences still exist between East and West Germany. These studies, ranging from labour markets and saving rates (Fuchs-Schündeln 2008; Uhlig 2008) to preferences towards the former political system (Alesina and Fuchs-Schündeln 2007) and differences in self-reliance due to cultural exposure (Bauernschuster et al. 2012), unanimously observe that differences still exist, indicating the persistence of pre-existing norms and values.

In the same vein, one stream of literature focuses on the entrepreneurial perspective. Entrepreneurial activity represents an important indicator of development for market economies, and most literature draws on Baumol's (1990) claim regarding the relevance of institutions, namely, that the number of potential 
entrepreneurs is similar across different societies, but a society's institutional framework determines whether this potential is actually exploited. According to Fritsch et al. (2015), lower self-employment rates in East Germany after reunification are explained mainly by the behavioural characteristics of the East Germans, having been exposed to the former GDR's norms and values. Similarly, Runst (2013) analyses the determinants of self-employment in reunified Germany and suggests that the probability of being self-employed is significantly lower for individuals socialised in East Germany. Behavioural differences between East and West German populations have been linked to individuals' personalities. For instance, Bauernschuster et al. (2012) relate the level of entrepreneurship with the level of self-reliance and find an association between lower self-reliance, as observed in East Germany, and lower self-employment. Similarly, Wyrwich (2013) finds that work experience is related to entrepreneurial activity, but this relation is lower for older East Germans than their West German counterparts.

While all the survey-based evidence indicates that entrepreneurial activity seems to be affected by the persistent norms and values of the former GDR, the differences in managerial decision-making between East and West Germany remain hitherto unexplored. Therefore, we focus on the subset of East and West Germans who decide to manage a firm and analyse their decisions rather than survey responses. In other words, while entrepreneurial activity varies between East and West Germany, we examine whether the specific individuals who choose to manage a firm differ in their decision-making.

We measure managerial decision-making through the level of corporate cash holdings because it serves as unconditional liquidity that is available at any time (Lins et al. 2010). Existing literature has developed several theories on why firms hold cash (e.g. transaction-costs motive or precautionary motive; see recent studies, such as Bates et al. 2009 or Weidemann 2019) and has highlighted its relevance for all firm sizes, which is crucial for this study, as our sample mainly comprises small- and medium-sized enterprises (SMEs). Further, we favour cash holdings as our variable of interest for managerial decisionmaking because setting the cash level represents a common corporate finance decision with a certain amount of variation over time. A low level of cash may increase the risk of sudden illiquidity for managers. Conversely, a high level of cash implies high opportunity costs resulting from low returns to cash and losing out on valuable investments. Managers face this trade-off when determining the firms' level of cash; thus, we examine whether East German managers differ from West German managers in this regard. On the one hand, given the sudden transformation of the legal and institutional framework from East Germany's socialism to West Germany's capitalism, as well as the myriad of studies that estimate the transition process to be complete, one would expect to see no differences in managerial decision-making, proxied by corporate cash holdings, between East and West Germany. On the other hand and as outlined above, differences between East Germany and West Germany have been observed in recent research. Therefore, we begin with an exploratory analysis of whether cash holdings differ between East and West German firms. 


\section{Data and first evidence}

\subsection{Data}

The firm data for 2004-2016 is drawn from Creditreform $\mathrm{AG},{ }^{3}$ which provides comprehensive coverage and a representative sample of active companies registered in Germany. To ensure that the dataset is appropriate, data cleaning is performed as follows: First, for appropriate firm location, we discard companies with consolidated financial statements and only retain firms with individual financial statements. Second, we delete incorporations, as the board of directors may include international managers. Third, we exclude firms that were founded before 1950. Fourth, following studies such as Fritsch et al. (2014) and Uhlig (2006), we discard firms located in Berlin. Lastly, banking, finance, insurance, real estate companies, as well as utilities, public administration, and defence companies are excluded, because of differences in their balance sheets and income statements.

Several plausibility checks are performed to eliminate visibly incorrect observations (that is, negative values for cash holdings, total assets, total sales, and tangible assets, or if cash holdings are larger than total assets). Finally, we require at least four consecutive years of observations for each firm to be available. ${ }^{4}$ To mitigate the potential impact of outliers, we trim variables at the 2.5 th percentile in both tails. The final dataset contains 14,823 firms with 89,018 firm-year observations, of which approximately $26 \%$ are included in the East German sample. Table 1 provides fullsample summary statistics for the dependent and all the main control variables (see Table 9 in the Appendix for an outline of variable construction).

Table 2 shows the summary statistics for East and West Germany separately and tests for the differences in means between the two regions. Furthermore, we explicitly differentiate between the full sample (Panel A) and an SME sample (Panel B) because SMEs are known to hold more cash than large-sized firms due to different economies of scale (Dittmar et al. 2003; Opler et al. 1999). Therefore, we also present all results for the full sample and the SME subsample in this study. For this purpose, we define SMEs according to $\$ 267$ of the German Commercial Code, based on the number of employees, total assets, and total sales (see Appendix Table 10 for details).

The first row of Table 2 depicts the cash to total assets ratio; the t-statistics indicate an economically and statistically significant difference between East and West German firms. Notably, this is the case for both the full sample (Panel A) and the SME subsample (Panel B). We further observe that East German firms are smaller in size, have higher tangible fixed assets, and tend to be younger. These differences are statistically significant based on the t-statistic for the differences in means. However, according to Garcia-Appendini (2018) and Imbens and Wooldridge (2009),

\footnotetext{
${ }^{3}$ Creditreform AG is a holding company providing core services like business intelligence and receivables management.

${ }^{4}$ Note that this procedure does not yield a survivorship bias. All results remain unchanged upon reestimating all models with at least two consecutive years of observations available (not tabulated).
} 
Table 1 Summary statistics

\begin{tabular}{lllllll}
\hline & Mean & Median & 25th Pct. & 75th Pct. & Std.Dev. & N \\
\hline Cash $_{t}$ & 0.119 & 0.059 & 0.013 & 0.176 & 0.146 & 89,018 \\
Operating cash flow $_{t-1}$ & 0.111 & 0.097 & 0.049 & 0.163 & 0.105 & 89,018 \\
Cash flow volatility $_{t-1}$ & 0.055 & 0.041 & 0.022 & 0.073 & 0.047 & 89,018 \\
Inventory $_{t-1}$ & 0.230 & 0.193 & 0.063 & 0.361 & 0.188 & 89,018 \\
Net $_{\text {working capital }}$ & 0.008 & 0.015 & -0.147 & 0.179 & 0.257 & 89,018 \\
${\text { Sales } \text { growth }_{t-1}}_{\text {Tangible assets }_{t-1}}$ & 0.063 & 0.034 & -0.047 & 0.132 & 0.236 & 89,018 \\
Debt $_{t-1}$ & 0.253 & 0.186 & 0.069 & 0.394 & 0.220 & 89,018 \\
Short-term bank debt $_{t-1}$ & 0.665 & 0.703 & 0.492 & 0.862 & 0.239 & 89,018 \\
Total assets $_{t-1}$ (in Mio. $\left.€\right)$ & 15.332 & 15.339 & 14.041 & 16.544 & 1.726 & 89,018 \\
Age $_{t}$ (in years) & 21.514 & 19.000 & 12.000 & 28.000 & 12.977 & 89,018 \\
\hline
\end{tabular}

This table reports summary statistics for the full sample. All variables except Cash flow volatility, Sales growth, Age and Totalassets are defined as ratios. The lower number of observations in Short-term bank debt is due to missing data. We refer to Table 9 in the Appendix for details on the variable construction. Variables with subscript $t-1$ are lagged by one year in the regression analysis

the normalised difference is more accurate than the t-statistic for large sample as t-statistics increase with rising sample size. As a rule of thumb, the critical level of normalised absolute differences is 0.25 . Normalised differences below this level imply that linear regression models are not sensitive to the specification. ${ }^{5}$ Nonetheless, this necessitates multivariate regression analyses to exclude the possibility of interdependencies with other firm characteristics and control for different sources of heterogeneity.

\subsection{Model specification}

The dependent variable is firms' cash holdings divided by total assets $\left(\operatorname{Cash}_{i, t}\right)$. We follow existing literature by using cash as a ratio of total assets and by specifying the econometric model (Bates et al. 2009; Opler et al. 1999; Phan et al. 2019). We additionally account for the firms' location (whether East or West Germany). Our regression model therefore reads as follows:

$$
\text { Cash }_{i, t}=\alpha+\beta \text { East }_{i}+\gamma X_{i, t}+D_{t}+D_{j}+\epsilon_{i, t},
$$

where $\operatorname{Cash}_{i, t}$ is the dependent variable, that is, firm $i$ 's cash holdings in year $t$ divided by firm $i$ 's total assets in year $t$. Our main independent variable of interest is East $_{i}$, which is a dummy variable that takes a value of 1 if the company is in

\footnotetext{
5 The normalised difference is calculated as follows: $\Delta_{x}=\frac{\overline{X_{1}}-\overline{X_{0}}}{\sqrt{S_{1}^{2}+S_{0}^{2}}}$, where $\overline{X_{1}}$ and $\overline{X_{0}}$ are the sample averages and $S_{1}^{2}$ and $S_{0}^{2}$ are the sample variances of variable $X$ in the East and the West sample, respectively (Garcia-Appendini 2018; Imbens and Wooldridge 2009).
} 


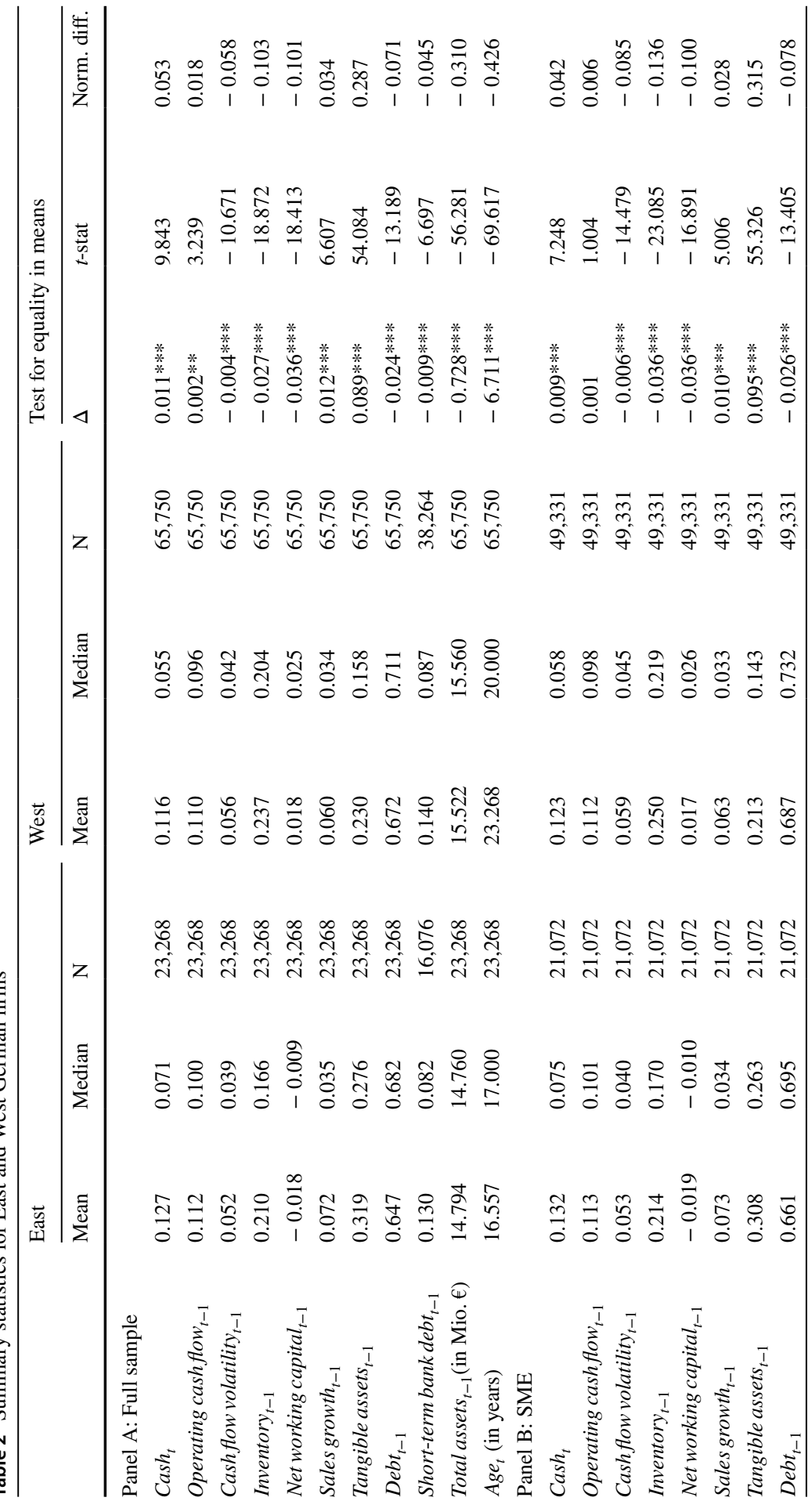




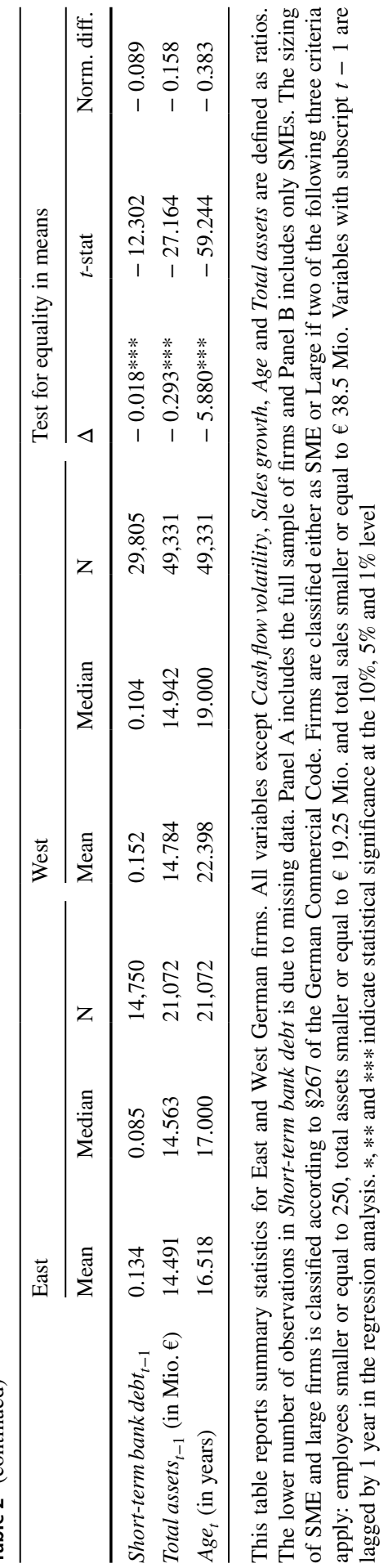


East Germany, and 0 otherwise (West Germany). If cash holdings between East and West German firms differ, we would expect $\beta$ in Eq. (1) to be significant. We apply a random-effects generalised least squares (GLS) model with year $\left(D_{t}\right)$ and industry fixed effects based on NACE2 Level 1 classification $\left(D_{j}\right)$, which allows us to control for heterogeneity across industries, business cycle fluctuations, and other life-cycle effects. $X_{i, t}$ represents a vector of control variables that are key determinants of corporate cash holdings, including operating cash flow, operating cash flow volatility, inventory, working capital net cash, sales growth, fixed assets labelled as tangible assets, total liabilities, the natural logarithm of total assets, and firm age (see Gao et al. 2013, for a detailed outline). To calculate operating cash flow volatility, we follow Keefe and Yaghoubi (2016) and use a minimum of 2 years; if more firmyear observations are available, a maximum of 5 years is used. This ensures proper measurement without the loss of too many observations. We also control for regionspecific economic developments by including the GDP per capita growth rate of the federal state in which the firm is located. ${ }^{6}$ To avoid simultaneity bias, all control variables except age are lagged by 1 year. Furthermore, analogous to the dependent variable, we scale all control variables, except cash flow volatility, sales growth, total assets, and firm age, by total assets. Considering that observations of the same firm over time are not independent, we cluster standard errors at the firm level.

\subsection{Results of the exploratory analysis}

Table 3 shows the main estimation results for Eq. (1) and includes additional robustness checks. First, Column (1) corresponds to the full sample and tests for differences in cash holdings between East and West German firms. There is a statistically significant difference in cash holdings between East and West German firms (represented by East). The cash level is significantly higher in East German firms, even after controlling for firm- and industry-specific characteristics. We observe the same for the SME subsample [Column (2)]. Note that these differences are also economically relevant, as the cash ratio of East German firms, on average, is $15 \%$ higher than that of West German firms (i.e. the coefficient of East (1.8\%) divided by the average cash ratio (11.9\%) from Table 1$)$.

Equation (1) assumes that the impact of the control variables is the same for East and West German firms. To relax this assumption and allow for different control variable coefficients for East and West German firms, we include interaction terms of all control variables with the East dummy. The estimation results are shown in Columns (3) and (4) of Table 3; the main observation remains unchanged with this

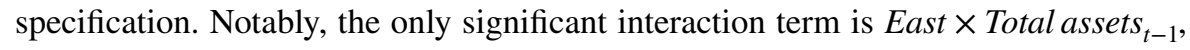

\footnotetext{
${ }^{6}$ In additional (unreported) robustness checks, we add macroeconomic variables that vary across federal states (i.e. the growth rate of gross capital investments, the growth rate of household savings, and the growth rate of employment) and replace GDP per capita with GDP per resident, GDP per work force, and GDP per working hour. Qualitatively, our results remain the same and are available upon request. The data on macroeconomic variables are sourced from https://www.statistikportal.de/de/vgrdl/ergeb nisse-laenderebene/bruttoinlandsprodukt-bruttowertschoepfung (28.05.2021).
} 


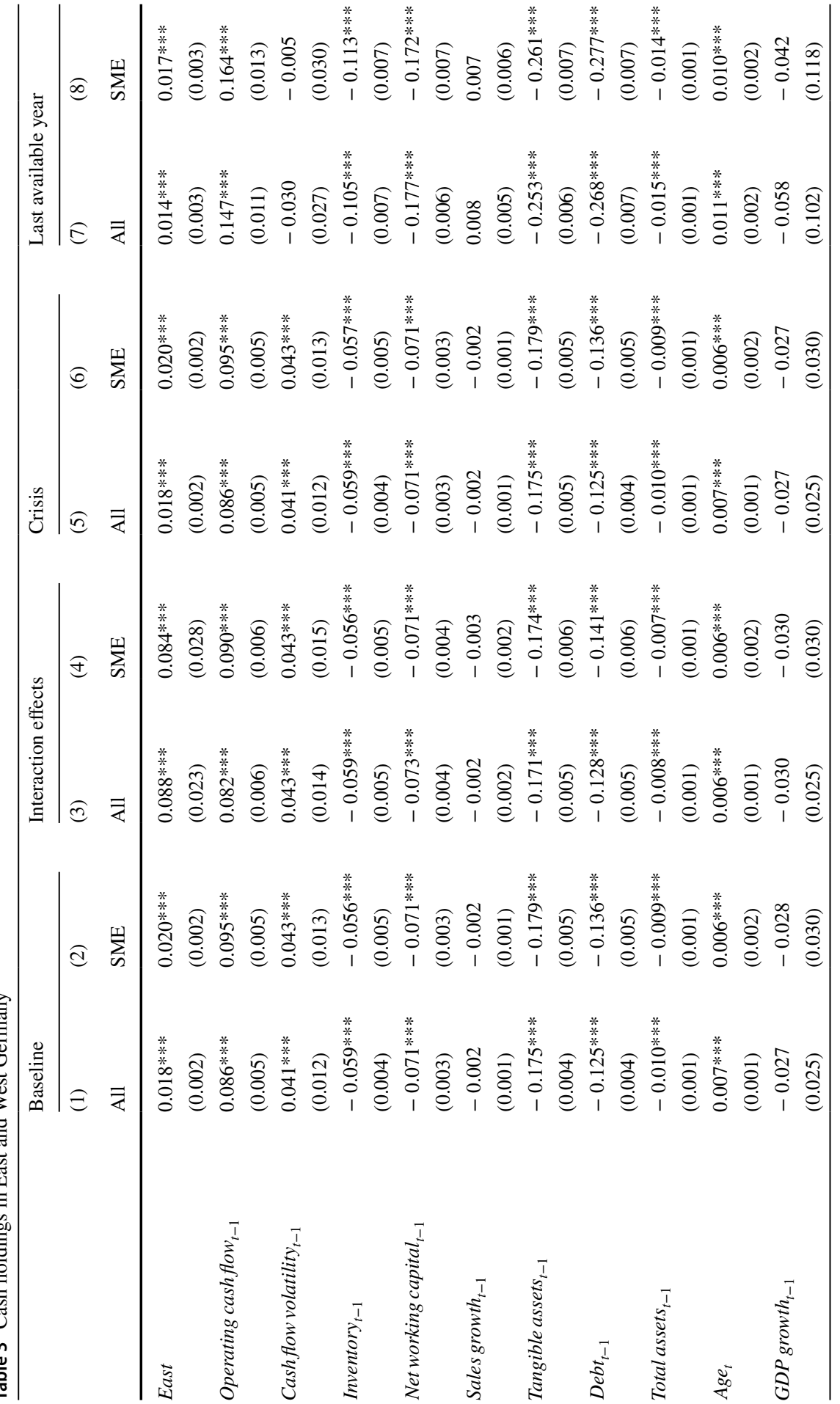




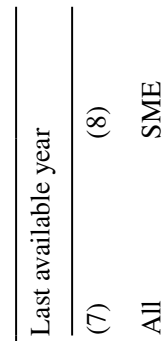

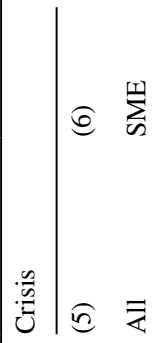

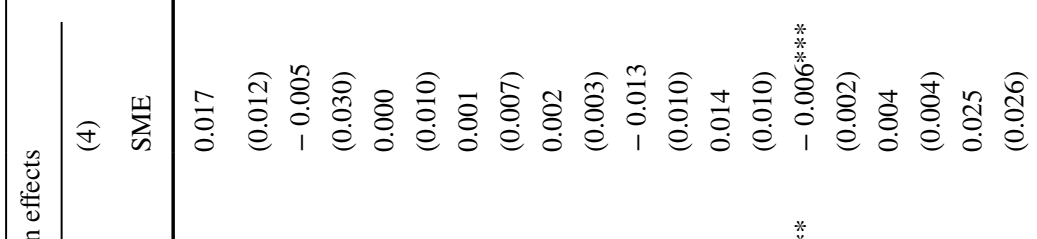

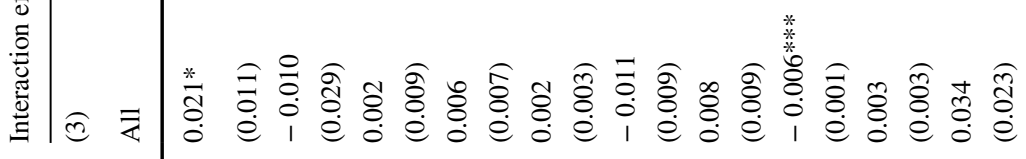

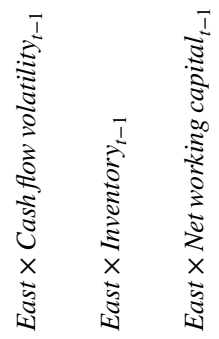

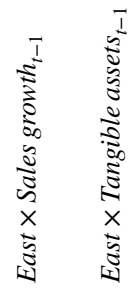

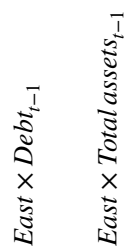

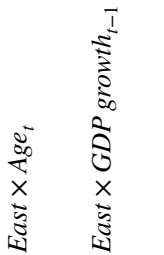




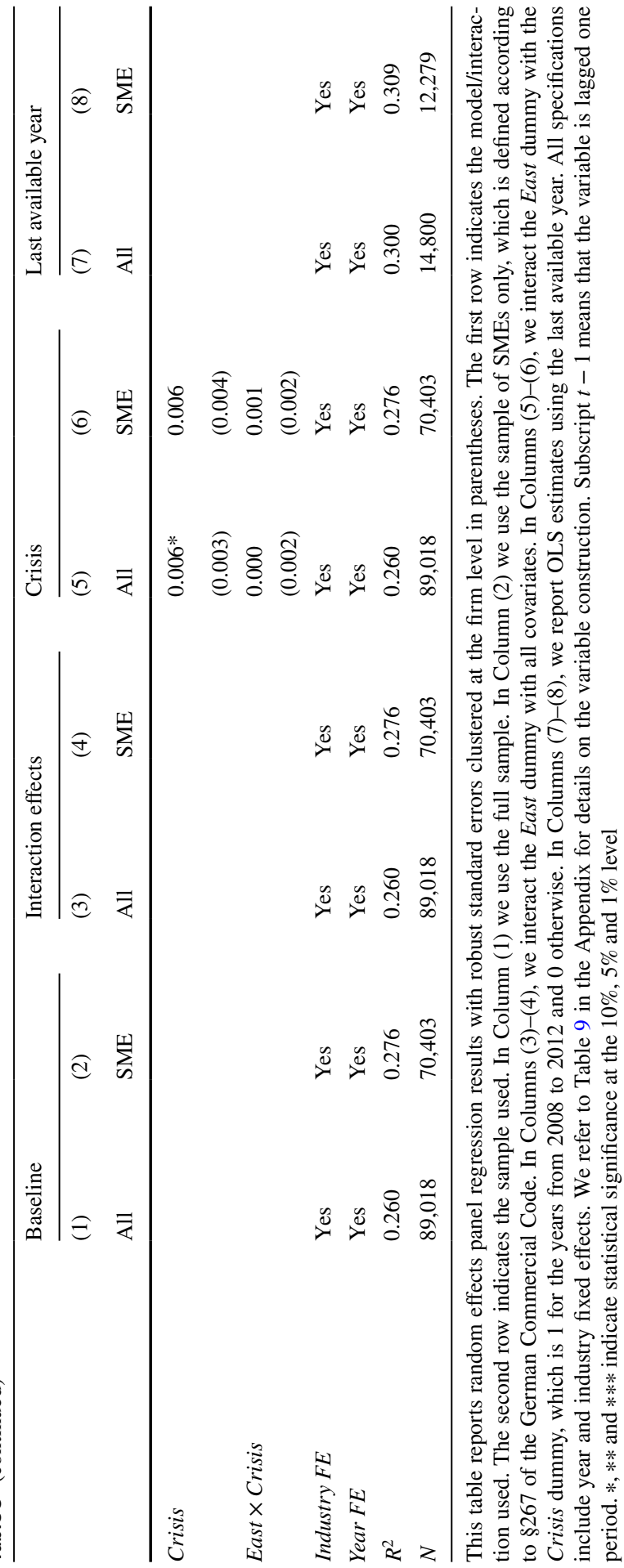


implying that firm size is differently correlated with cash holdings for East and West German firms. We address this observation in more detail in Sect. 5.1.

In the above-mentioned baseline estimations, we emphasise the dummy variable in East to analyse differences in corporate cash holdings between East and West German firms and further test the economic and econometric robustness of this finding. First, while the results indicate that the cash holdings of East and West German firms are significantly different, it is ambiguous whether this is true for all East German regions. To test the consistency of our analysis, we re-estimate the baseline regression using federal state-specific dummy variables. Further differences in regional economic growth are accounted for by adding aggregated federal state-specific growth rates of household savings, gross capital investment, and employment as controls. Figure 1 shows a heat map of Germany using the coefficients of the individual federal states as underlying data after estimating Eq. (1) for the full sample, with Baden-Württemberg as the reference state. The results suggest that cash holdings are significantly higher across all East German federal states.

Second, our sample period includes the 2008 financial crisis, which may have had a potentially confounding effect in terms of its different impact on East and West German firms. If firms were constrained from acquiring loans during the financial crisis because of any latent causes such as liquidity shortfalls or bank distress, cash holdings would be higher as a substitute for absent institutional credit during the credit crunch (Bedendo et al. 2020). Consequently, the present results may simply capture these distortions. A difference in cash holdings would be observed if, for instance, East German firms were more financially constrained and compelled to stockpile more cash as an alternative funding source. To test for this, we re-estimate the baseline specification in Eq. (1) as follows: We include a dummy variable Crisis, which takes a value of 1 for the crisis years (from 2008 to 2012), and 0 otherwise, as well as an interaction term East $\times$ Crisis, which allows us to disentangle the differences in cash holdings between East and West German firms during the financial crisis. The results shown in Columns (5) and (6) of Table 3 suggest that the financial crisis did not affect the East dummy. East German firms hold more cash independent of the financial crisis.

Third, to exclude the possibility that the significant differences in cash holdings are driven by sample size, we re-estimate Eq. (1) using only the last available year for each firm. This robustness test further addresses the possibility of serial correlation within our estimates (Bertrand et al. 2004) as the analysis period is quite long (i.e. maximum of 13 years). Because our variable of interest - the East dummy-does not vary over time, the standard error for $\hat{\beta}$ in Eq. (1) can underestimate its standard deviation. The robustness check results are tabulated in Columns (7) and (8) of Table 3. The coefficients and standard errors are similar to our baseline results; thus, we may conclude that the results are not driven by serial correlation or sample size.

Finally, we replace the dependent variable with alternative definitions of cash holdings by using the natural logarithm of cash holdings to total assets $\left(\log \left(\operatorname{Cash}_{i, t}\right)\right)$ and the natural logarithm of cash holdings to net total assets $\left(\log \left(\right.\right.$ Net Cash $\left.\left._{i, t}\right)\right)$ to account for extreme outliers (Bates et al. 2009; Foley et al. 2007; Opler et al. 1999). These alternative specifications yield similar results to those presented in Table 3, indicating that using the cash-to-assets ratio is appropriate (not tabulated). 
Fig. 1 Cash holdings-Federal states. This figure depicts a heat map with the coefficients of German federal states for a random effects panel regression with robust standard errors clustered at the firm level. The regression model is given by: Cash $_{i, t}=\alpha+\beta$ Federal state f $_{f}$ $+\gamma X_{i, t}+D_{t}+D_{j}+\epsilon_{i, t}$, while the reference state is BadenWürttemberg. Covariates are the same as those mentioned in Sect. 3.2. To account for potential differences in economic growth among the various federal states, the following macroeconomic variables are included: lagged growth rate of gross capital investment, lagged growth rate of household savings and lagged growth rate of employment. The values in the legend indicate the size range of the coefficients for the respective colour class. The black bold line displays the border of the former GDR

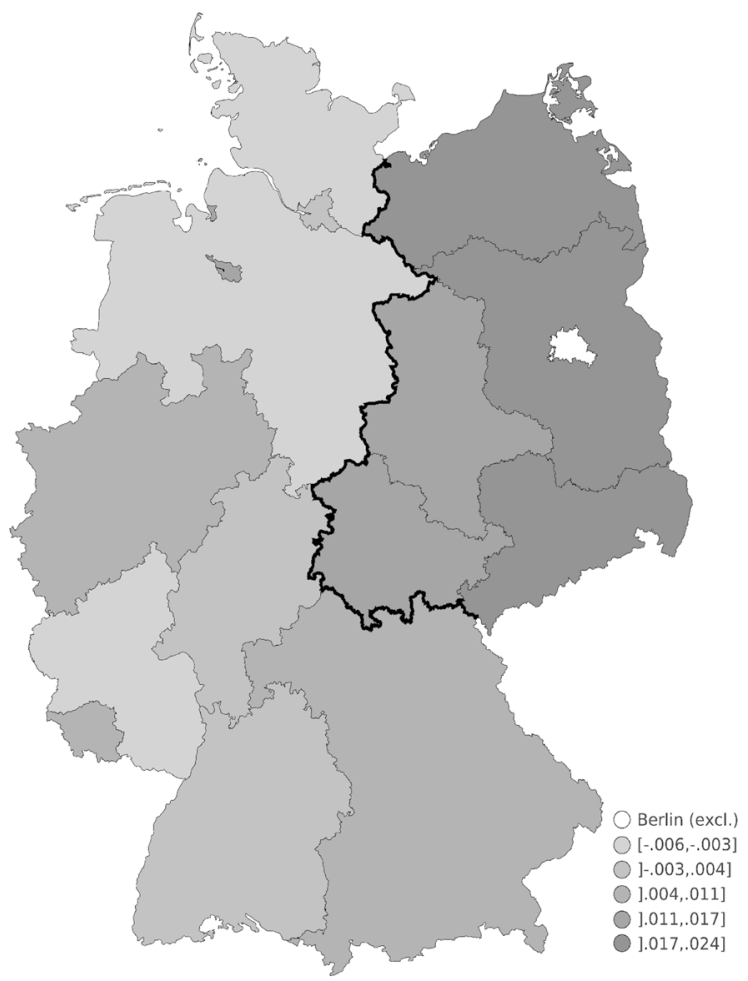

\section{Possible explanations}

The main observation in Sect. 3.3 demonstrates significant and robust differences in cash holdings between East and West German firms. However, this does not necessarily imply differences in managerial decision-making. Several reasonable, empirically validated explanations that stem from economic theory may hold as well. We thus address the most important ones in the following subsections.

\subsection{Structural differences}

On average, East German firms are smaller, younger, and have fewer tangible assets than West German firms (see Table 2). Consequently, the observed difference in cash holdings may emerge from an 'unbalanced' sample. While SMEs have been considered separately in our baseline estimation, structural differences between East and West German SMEs may still exist. Cash holdings are highly dependent on a firm's industry, and larger firms usually hold less cash due to economies of scale (Dittmar et al. 2003; Opler et al. 1999). Several economic theories explain these differences in capital structure. Pettit and Singer (1985) argue that a debt tax shield has little importance for smaller firms since its objective-generating high profits-is less relevant for them. Second, information asymmetry is higher for smaller firms, 
as their typical opaqueness implies high information costs for banks (Psillaki 1995). Third, Jensen and Meckling's (1976) agency theory holds little importance for smaller firms, as most of them are owned and managed by the same person. Thus, smaller firms mainly rely on internal financing, avoid debt, and are expected to hold more cash (Daskalakis et al. 2013). To mitigate the potential effect of structural differences, we create a 'balanced' sample by applying a propensity score matching which constructs a most similar sample of East and West German firms.

The propensity score is calculated as the probability of a West German firm $i$ matching an East German firm, given its set of variables $X_{i}$ (i.e. $P_{i}(X)=\operatorname{Prob}\left(\right.$ East $\left.\left._{i}=1 \mid X_{i}\right)\right)$. The variables of interest in $X_{i}$ are total assets, average number of employees, average total sales, average tangible fixed assets, and age. Additionally, firms that match must be in the same industry (two-digit NACE2 code). To enhance accuracy, we allow for matching with replacement, as applied by Garcia-Appendini (2018).

Panel A of Table 4 presents the summary statistics for the firm-characteristic matched sample. Notably, all normalised differences between East and West German firms now lie considerably below the critical level of 0.25 , and the t-statistics are substantially lower. Thus, firm-characteristic matching makes the sample more homogenous. We re-estimate Eq. (1) to analyse whether similar firms in East and West Germany still differ in their level of cash holdings. The results are tabulated in Columns (1) and (2) in Panel C of Table 4 and are identical to the baseline estimation in Table $3 .^{7}$

While propensity score matching ensures that East and West German firms are similar in terms of firm characteristics, these firms may be geographically very distant. For example, a West German firm can be close to Switzerland, while its matched East German counterpart is close to the Polish border. To account for this aspect, we also 'geographically' match our sample by selecting only firms that are-based on the firms' postal code_close to the former border between East and West Germany. Figure 2 shows the respective areas in East and West Germany, from which we select the relevant firms for this exercise. The summary statistics of the location-based matching are tabulated in Panel B of Table 4. The re-estimation of Eq. (1) does not change our initial finding of higher cash holdings in East German firms (see Columns (3) and (4) in Panel C, Table 4). Note that the sizes of the full sample differ only slightly, indicating that firms located in this area are mainly SMEs.

We consequently conclude that the baseline regression results in Sect. 3.3 are not driven by potential structural differences, as neither the firm-characteristic matching nor the location-based matching changes our main observation of higher cash holdings in East German firms. ${ }^{8}$

\footnotetext{
7 For robustness, we also limit the absolute differences of all matching variables for each matched pair. More specifically, we keep a matching pair when each variable difference is lower than one (two) standard deviation(s) from the mean difference of the matched sample. While the number of observations decreases considerably to $19,457(43,515)$ for the case of one (two) standard deviation(s), the results remain qualitatively and quantitatively the same (not tabulated).

8 Note that we also combined location-based matching by keeping only firms in that area and applying propensity score matching afterwards. Due to the low number of firms after location-based matching $(14,186$ firm-years for 2406 firms in total), appropriate firm-characteristic matching is no longer possible.
} 


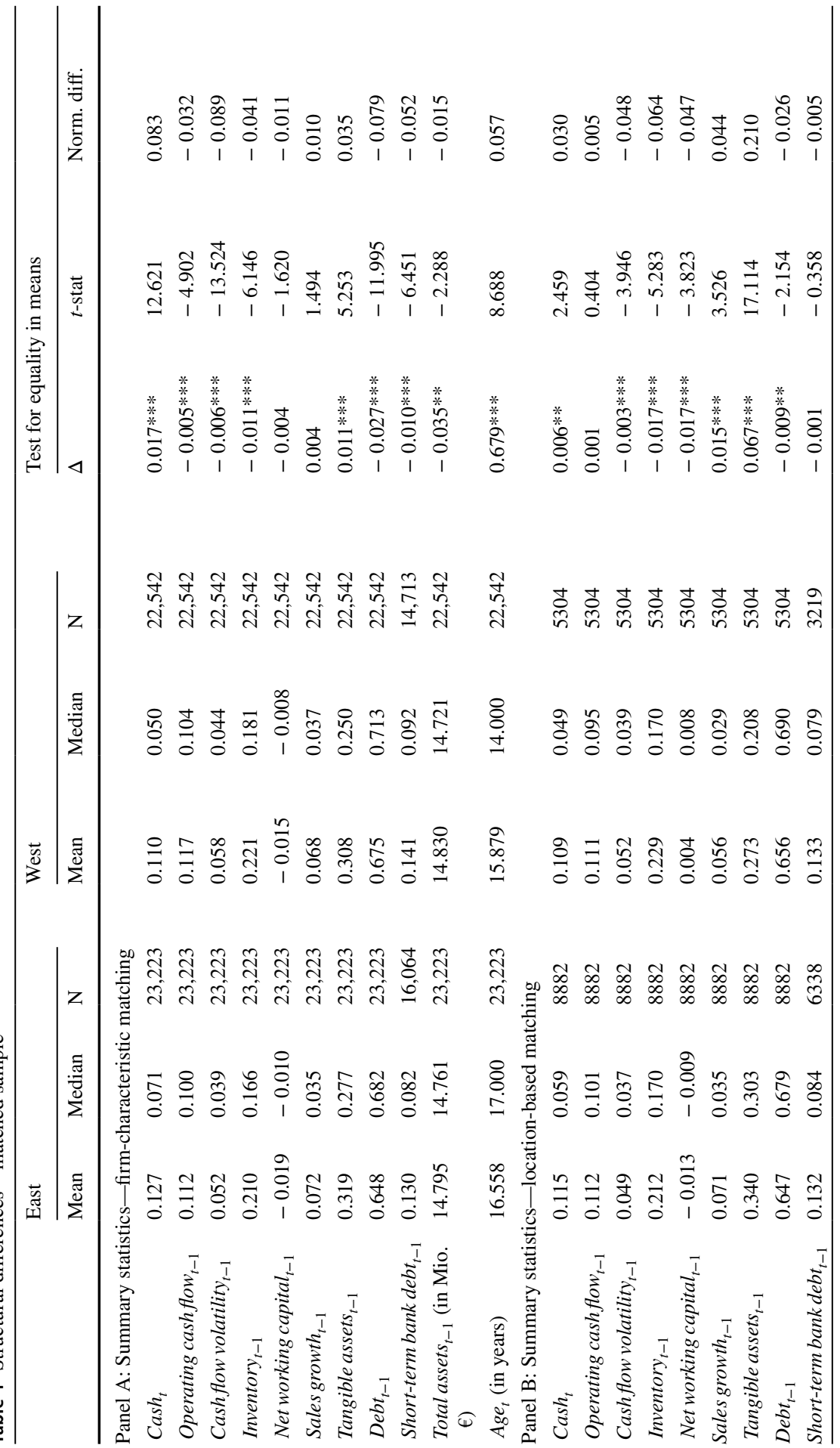




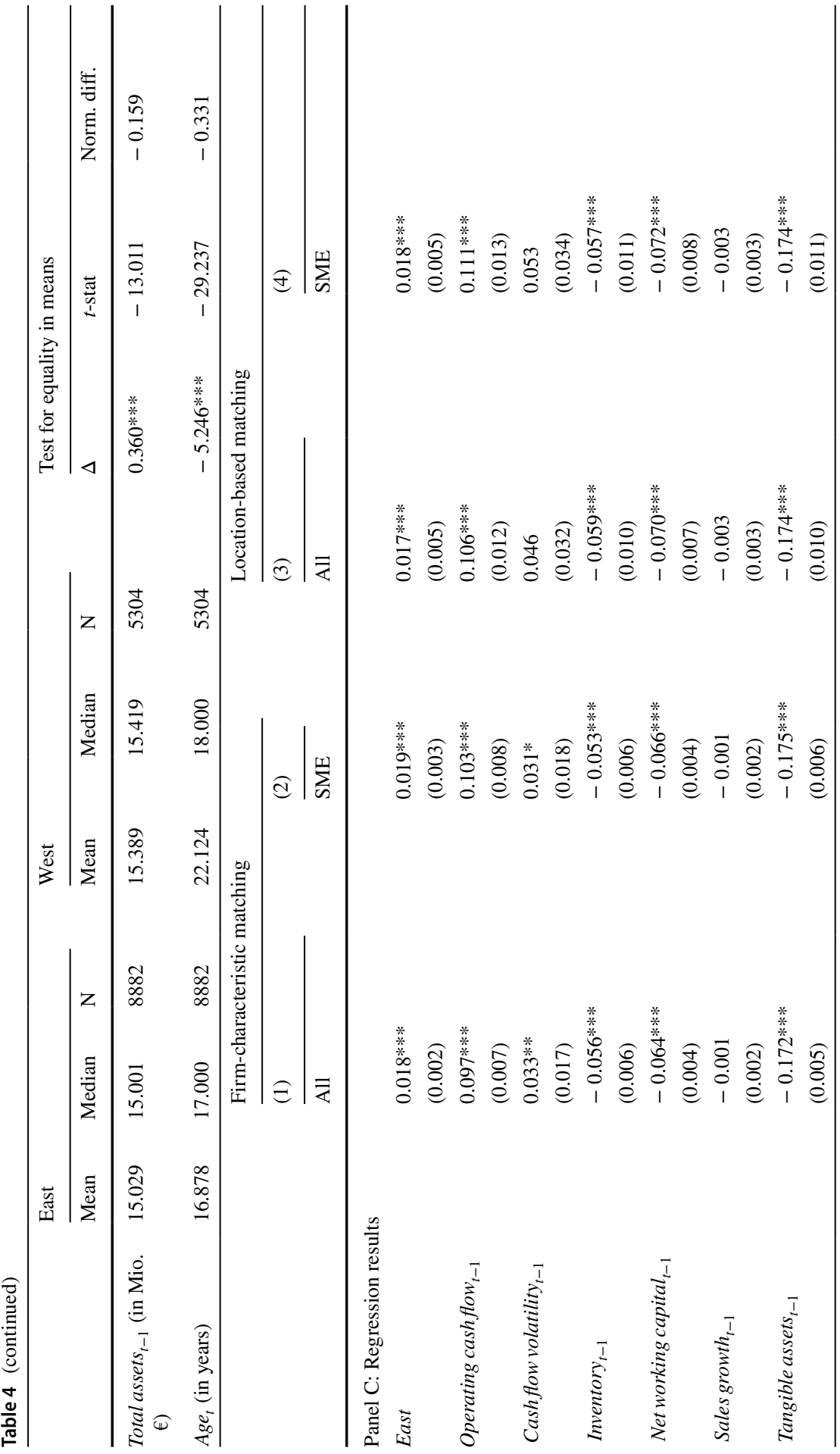




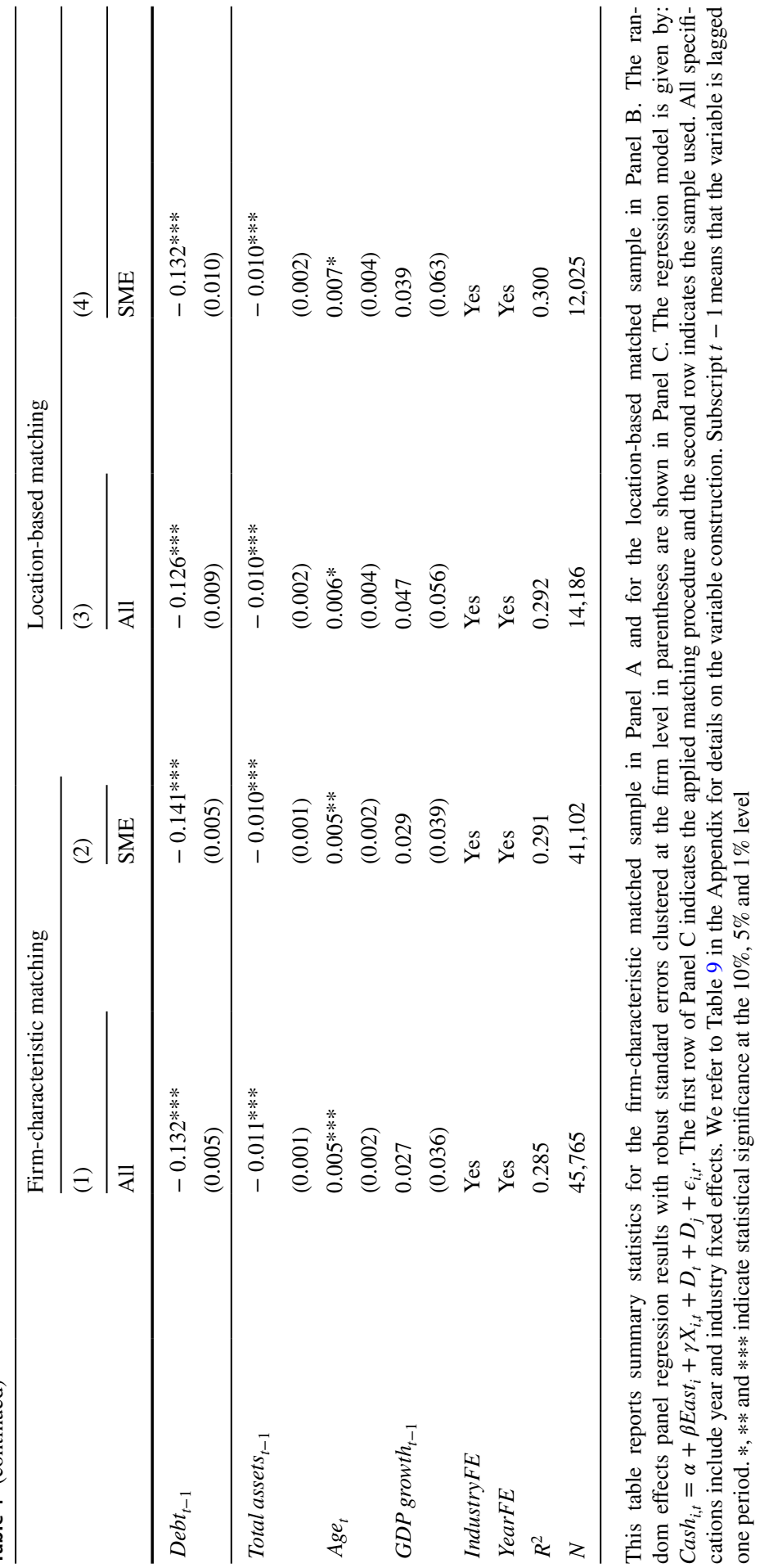


Fig. 2 Relevant area for location-based matching. This figure shows the selected area for the location-based matching. Darkgrey (mid-grey) colour indicates the relevant area for East (West) German firms to be selected for the location-based matching. Light-grey colour indicates the area of the remaining parts of East and West Germany that is not used for this analysis. The black bold line displays the border of the former GDR

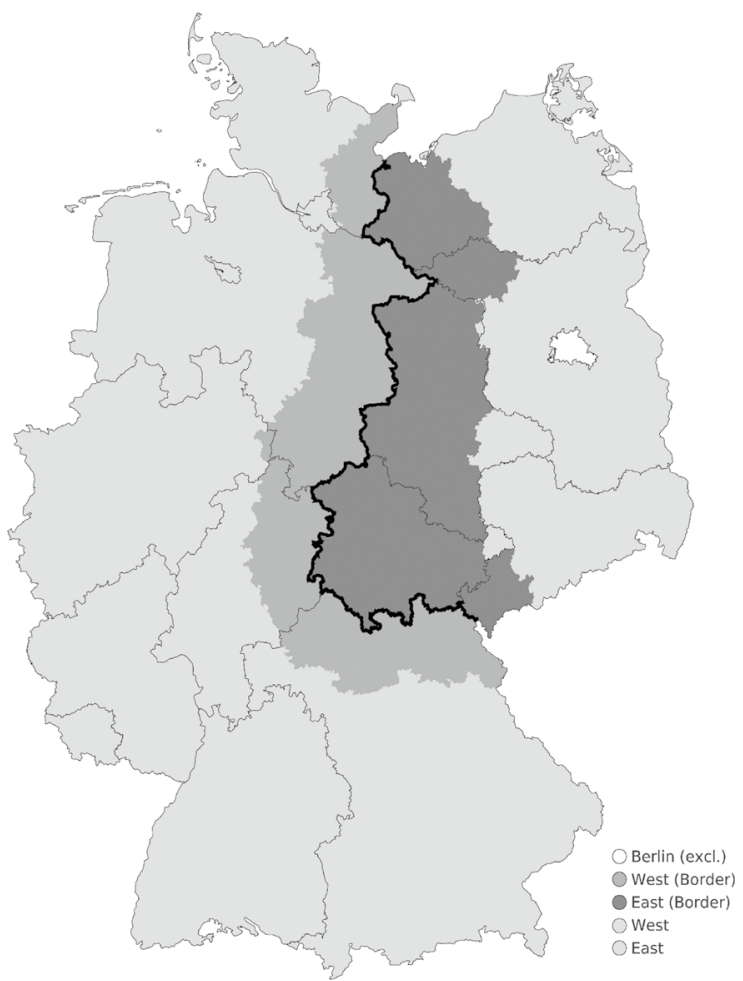

\subsection{Different access to financing}

Lehmann et al. (2004) document either worse or more expensive access to external finance for East German firms. East German firms in industries with higher external finance dependence may thus be forced to save more cash to avoid losing valuable investment opportunities. Therefore, we test whether dependence on external finance can explain the differences in cash holdings. As industry-level measures of external finance dependence are generally claimed to be more exogenous than individual firm measures (Duchin et al. 2010; Garcia-Appendini and Montoriol-Garriga 2013), we follow Rajan and Zingales (1998) to calculate an industry-level measure of external finance dependence for firm $i$ in industry $j$ with $E F D_{i, j}$. More specifically, we calculate $\frac{\text { CAPEX }_{i, t} \text { Operating cashflow }_{i, t}}{C A P E X_{i, t}}$ for each firm-year observation, where CAPEX is capital expenditure. We then use the sample and industry (two-digit NACE2) medians to determine whether a firm belongs to an industry with high external finance dependence (that is, its industry's median lies above the sample median). Columns (1) and (2) of Table 5 indicate that external finance dependence negatively affects corporate cash holdings. To further test whether East German firms in highly dependent industries react differently than West German firms, we include an interaction term $\left(\right.$ East $\left.\times E F D_{j}\right)$. However, East German firms acting in industries with high external finance dependence are not observed to pre-emptively save more cash. Consequently, dependence on external 
finance cannot explain the differences in cash holdings between East and West German firms, as the dummy variable East remains statistically significant.

To account for the broader relationship between external capital and internal funds, the idea of financial constraints emerged (Fazzari et al. 1988). Financially constrained firms typically rely more on internal funds than on external capital, and as a result, hold more cash. To control whether financial constraints drive our main observation, we must first determine which firms are financially constrained. While the Kaplan and Zingales (1997) index is an established method to identify financially constrained firms, the index is designed for publicly-listed firms and cannot be applied to private firms. Schauer et al. (2019) propose an alternative financial constraints index, which targets private firms and can also be applied to SMEs. To calculate the financial constraints index for private firms (FCP), only four variables are needed-total assets, interest coverage, return on assets, and cash holdings. ${ }^{9}$ To identify financially constrained firms, we categorise all firms into terciles based on their FCP index value for each year. All firms in the bottom tercile (i.e. 33\% firms with the lowest FCP index value) are indicated to be financially constrained. To examine whether our results are driven by such firms, we create a dummy variable Constrained $_{i, t}$, that takes a value of 1 if firm $i$ is in the bottom tercile of the FCP index in year $t$, and 0 otherwise. The results including Constrained Cond $_{t}$ ane interaction term East $\times$ Constrained $_{t}$ in the baseline estimation are shown in Columns (3) and (4) of Table 5. The dummy variable Constrained C $_{t}$ is positive and statistically significant. Thus, in line with economic theory, financially constrained firms hold significantly more cash. However, the insignificant interaction term indicates that there is no difference between financially constrained East and West German firms. As the dummy variable East remains statistically significant, we further conclude that our main observation is not driven by financially constrained firms.

Acharya et al.'s (2007) model examines financially optimal cash-debt substitutability and predicts situations in which the relationship between cash holdings and debt varies. Thus, some firms may favour short-term bank debt instead of cash. Therefore, we control for a firm's level of short-term bank debt. We add the control variable Short-termbank debt $t_{i, t-1}$ and the interaction term East $_{i} \times$ Short-term bank debt $_{i, t-1}$. The latter allows for different coefficients between East and West German firms. The results are shown in Columns (5) and (6) of Table 5. While the negative and significant coefficient of Short-term bank debt $t_{t-1}$ indicates that it is in fact a substitute for cash holdings, the insignificant interaction term East $\times$ Short-term bank debt $t_{t-1}$ implies that there is no difference between East and West German firms. Moreover, the significant positive effect of East remains, implying that East German firms do not hold significantly more cash than West German firms because of a worse or more expensive access to short-term bank debt. ${ }^{10}$

\footnotetext{
9 Table 9 in the Appendix provides the equation for the FCP index calculation.

${ }^{10}$ We also use a more exogenous measure of bank debt to account for access to bank financing, that is, the yearly growth rate of the aggregate granted bank loan volume for each federal state. The results are similar, indicating that aggregate growth in federal bank debt is not related to the cash holdings of federal state-specific firms (not tabulated). The data on the aggregated bank loan volume is available on https:// www.bundesbank.de/en/statistics/banks-and-other-financial-corporations (28.05.2021).
} 


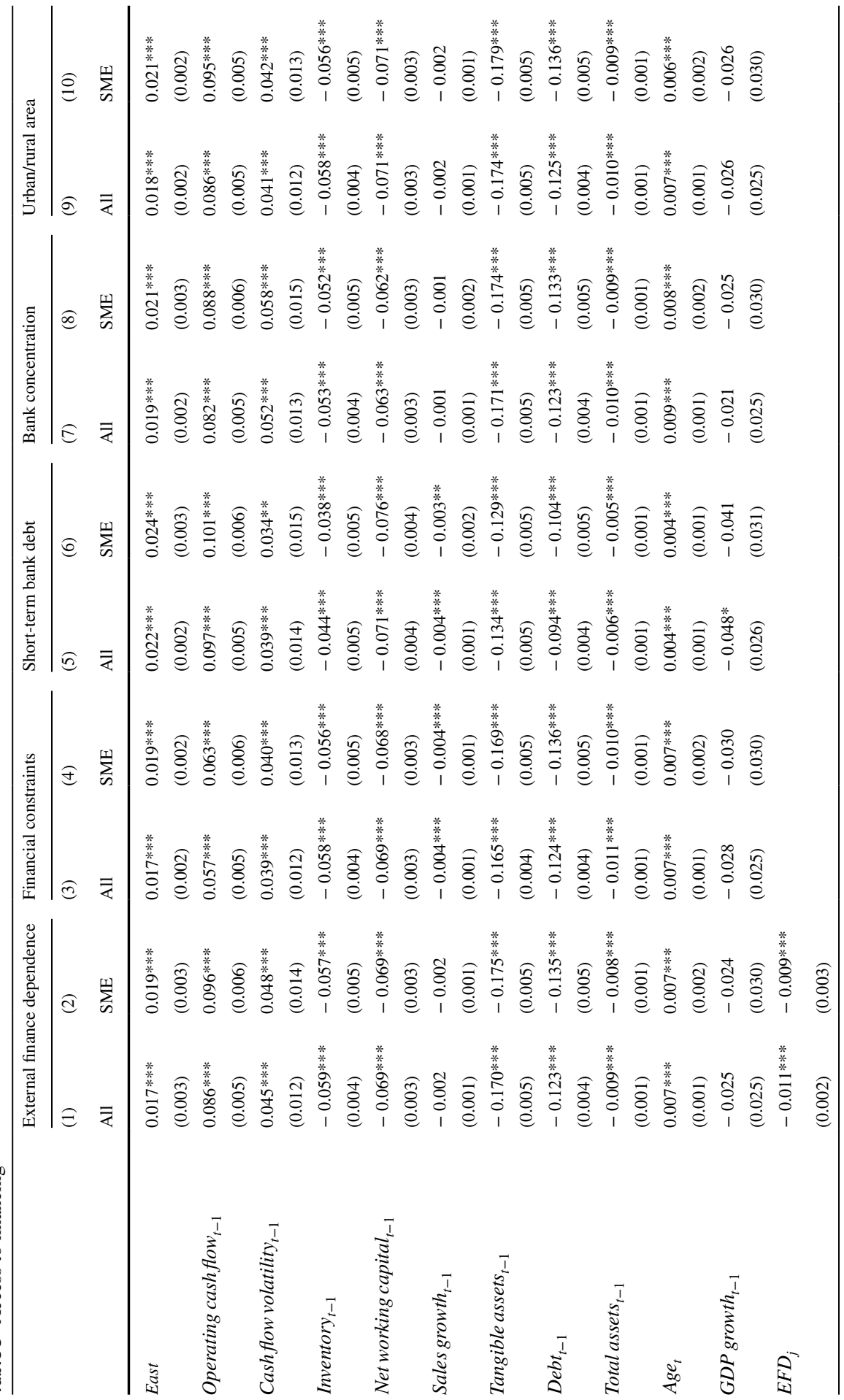




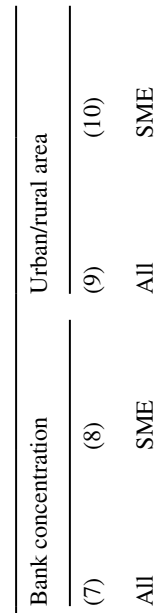

$\begin{array}{llll}* & & \\ * & & 0 & \\ * & 0 & 0 \\ 0 & 0 & 0 \\ 0 & 0 & 0 \\ 1 & 0 & 1 & e\end{array}$

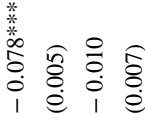

泀
옹

홍

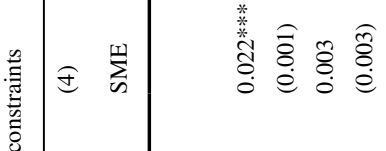

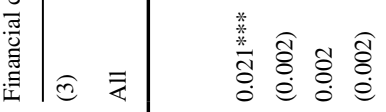

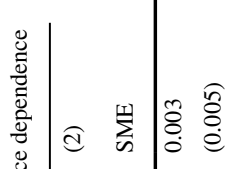

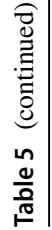

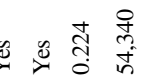

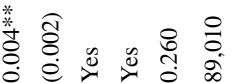

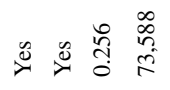

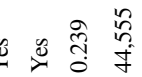

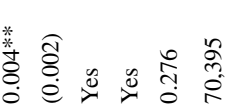

क人ิ่

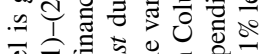

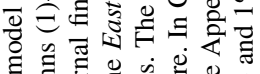

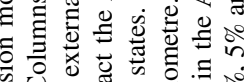

कू

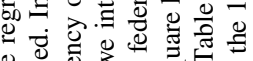

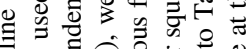

ए 凹

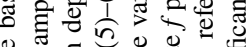

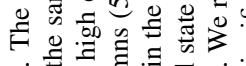

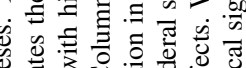

ฮ

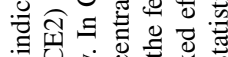

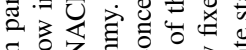

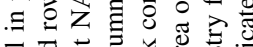

Ð

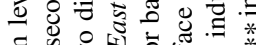

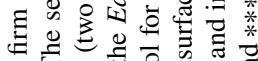

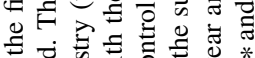

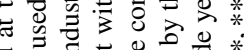

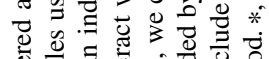

㐘

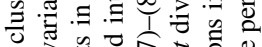

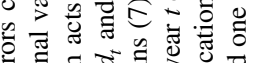

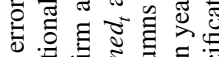

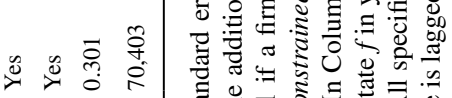

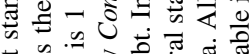

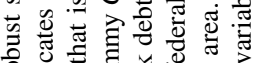
और

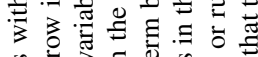

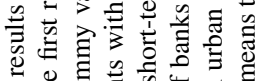

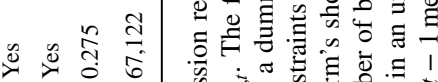

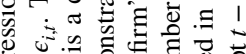

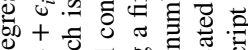
$0 \cdot \frac{0}{3} \cdot \frac{\pi}{0} .000$

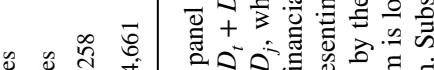

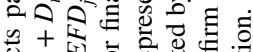

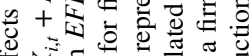

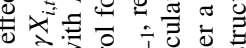

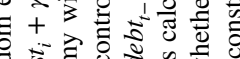

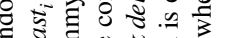

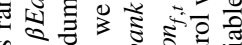

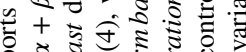

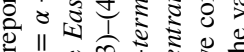
चव ल

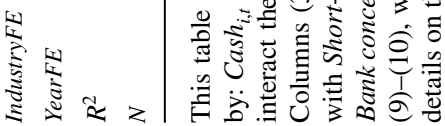


Agarwal and Hauswald (2010) document that the distance between a lender and a bank is negatively related to the loan rate due to asymmetric information. ${ }^{11}$ As shown by González and González (2008), pecking order theory also relates to the level of bank concentration-higher information asymmetries due to the banking concentration increase a firm's usage of internal funds (i.e. cash holdings). Put differently, the closer a bank is to a firm, the less relevant the information asymmetries and, ceteris paribus, the lower the interest rate demanded. Thus, regional bank concentration, as an institutional factor, may affect the financing structure of a firm, and consequently, its cash holdings. As shown by Bernhardt and Schwartz (2015), East Germany has a lower regional bank concentration than West Germany, which, based on the pecking order theory, may explain the differences in cash holdings. To control for the effect of regional bank concentration, we add the control variable Bank concentration $_{f, t}$ as the federal bank concentration $f$ in year $t$. The variable is computed by dividing the total number of branches of German savings banks and credit unions (i.e. Sparkassen-und Genossenschaftsbanken) by the federal state area (in square kilometres) for each year. ${ }^{12}$ While there are substantial differences in our proxy for bank concentration across German federal states and over time, Columns (7) and (8) of Table 5 suggest that bank concentration is unrelated to corporate cash holdings.

Further, Arena and Dewally (2012) observe that firms located in rural areas face higher interest expenses on their outstanding debt. Firms located in urban areas are closer to their banks which lowers potential information asymmetries and consequently facilitates borrowing. Therefore, firms located in rural areas may keep more cash to substitute costly bank debt which would lead, based on the pecking order theory, to the same conclusion as above (González and González 2008). Firms located in rural areas might not have unrestricted access to external capital markets and thus highly depend on their own operating cash flow. As the marginal value of cash is higher for rural firms, they experience cash constraints. To examine whether our results are driven by a firm's location, we control for the type of town or munic-

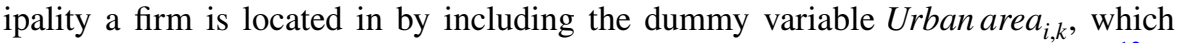
equals 1 if firm $i$ is domiciled at least in a medium-sized town, and 0 otherwise. ${ }^{13}$ If an urbanisation effect drives our results, a negative coefficient would be expected for urban firms, while the effect of East diminishes. As shown in Columns (9) and (10) of Table 5, the dummy variable Urban area $_{k}$ is positive and statistically significant. Thus, urban firms are found to have significantly higher cash levels, extending the findings of González and González (2008). Nonetheless, it does not change our main observation that corporate cash holdings are significantly higher in East Germany.

\footnotetext{
11 See Degryse and Ongena (2005) for an overview of alternative models on lender distance and loan rates.

12 The current number of bank branches is provided by the Deutsche Bundesbank and available on https://www.bundesbank.de/en/statistics/banks-and-other-financial-corporations (28.05.2021). The authors gratefully acknowledge the support of the Deutsche Bundesbank for providing historical data on the number of bank branches.

13 The data on the type of a town or municipality are available at https://www.bbsr.bund.de/BBSR/DE/ forschung/raumbeobachtung/downloads/downloadsReferenz2.html (28.05.2021).
} 
Table 6 Historical differences

Founded after 1990

(1)

All

East

East

Operating cash flow $_{t-1}$

(0.003)

$0.092 * * *$

$$
\text { (0.006) }
$$

Cash flow volatility $_{t-1}$

$$
0.039 * *
$$

Inventory $_{t-1}$

$-0.049 * * *$

(0.005)

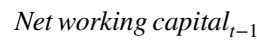

$-0.070 * * *$

(0.004)

Sales growth ${ }_{t-1}$

$-0.002$

(0.002)

Tangible assets $_{t-1}$

$-0.171 * * *$

(0.006)

Debt $_{t-1}$

Total assets $_{t-1}$

$-0.127 * * *$

(0.005)

$-0.011 * * *$

(0.001)

$0.004 *$

(0.002)

$-0.005$

(0.033)

Entr. roots. $r$

IndustryFE

YearFE

$R^{2}$

N

Yes
Yes
0.271
53,180

(2)

SME

$0.019 * * *$

(0.003)

0.096 ***

(0.007)

$0.042 * *$

(0.017)

$-0.046^{* * * *}$

(0.006)

$-0.072 * * *$

(0.004)

$-0.002$

(0.002)

$-0.173^{* * * *}$

(0.006)

$-0.141^{* * *} *$

(0.006)

$-0.011 * * *$

(0.001)

0.004

(0.003)

$-0.003$

(0.039)
Entrepreneurial roots

(3)

(4)

All

SME

$\begin{array}{ll}0.018^{* * * *} & 0.020 * * * \\ (0.002) & (0.002) \\ 0.086^{* * * *} & 0.095 * * * \\ (0.005) & (0.005) \\ 0.042^{* * * *} & 0.043 * * * \\ (0.012) & (0.013) \\ -0.059 * * * & -0.056^{* * *} \\ (0.004) & (0.005) \\ -0.072 * * * & -0.071^{* * *} \\ (0.003) & (0.003) \\ -0.002 & -0.002 \\ (0.001) & (0.001) \\ -0.175 * * * & -0.180^{* * *} \\ (0.005) & (0.005) \\ -0.125 * * * & -0.137 * * * \\ (0.004) & (0.005)\end{array}$

$-0.010 * * *$

$-0.009 * * *$

(0.001)

(0.001)

$0.007 * * *$

$0.006 * * *$

(0.001)

(0.002)

$-0.028$

$-0.029$

(0.025)

(0.030)

0.000

0.002

(0.002)

(0.002)

Yes

Yes

Yes

Yes

0.276

0.287

0.260

69,733

This table reports random effects panel regression results with robust standard errors clustered at the firm level in parentheses. The baseline regression model is given by: Cash $_{i, t}=\alpha+\beta$ East $_{i}+\gamma X_{i, t}+D_{t}+D_{j}+\epsilon_{i, t}$. The first row indicates the time/additional variable used. The second row indicates the sample used. In Columns (1)-(2), we interact the East dummy with all firms in our sample that were founded after 1990. In Columns (3)-(4), we control for historical entrepreneurial roots in a German region $r$. All specifications include year and industry fixed effects. We refer to Table 9 in the Appendix for details on the variable construction. Subscript $t-1$ means that the variable is lagged one period. $*, * *$ and $* * *$ indicate statistical significance at the $10 \%, 5 \%$ and $1 \%$ level 
Overall, the results in Table 5 indicate that the differences in corporate cash holdings between East and West German firms are not caused by differences in access to financing. Although factors relevant to access to financing are correlated with cash holdings, the difference between East and West German firms remains significant in all specifications.

\subsection{Historical differences}

Fritsch et al. (2014), among others, highlight the existence of anti-entrepreneurship strategies of the former GDR and the resulting low rates of self-employment. Political pressure may be the reason why pre-reunification East German firms are different from those founded after 1990. Thus, to exclude the possibility of adverse selection, we re-estimate the baseline regression in Eq. (1) and include only firms that were founded after 1990. Columns (1) and (2) of Table 6 indicate that the East dummy does not change for this subsample. Thus, East German firms founded after reunification also hold significantly more cash.

Fritsch and Wyrwich (2014) highlight the impact of early historical differences, considering Germany's entrepreneurial spirit during the 1920s, on entrepreneurship in Germany. These differences are measured by the distribution of self-employed persons in non-agricultural sectors across German regions in 1925. The authors show that the correlation between the 1925 self-employment rate and the selfemployment and start-up rates for the 1984-2005 period is significantly positive, implying the long-term persistence of these historical differences. Thus, it is possible that the observed differences in cash holdings may be caused by these historical entrepreneurial roots in Germany. To test this hypothesis, we use Fritsch and Wyrwich's (2014) information about historical entrepreneurial roots and create a dummy variable that equals 1 if self-employment was above a specific level in region $r$, and 0 otherwise. ${ }^{14}$ We extend the baseline regression in Eq. (1) including this dummy

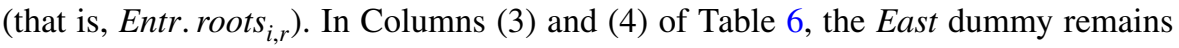
statistically significant after controlling for historical entrepreneurial differences. In addition, the insignificant coefficient of Entr. roots ${ }_{r}$ indicates that corporate cash holdings are not related to historical differences in entrepreneurship.

We thus conclude that historical differences, whether due to political pressure or early entrepreneurial spirit, do not explain the difference in corporate cash holdings between East and West German firms.

\section{Potential differences in cultural attributes}

In the previous section, we considered several meaningful hypotheses to explain the differences in cash holdings between East and West German firms, however, none of them can do so. In the light of the existing literature that observes differences in

\footnotetext{
14 More specifically, we use Figure 6 in Fritsch and Wyrwich (2014) and create a dummy variable that is 1 if the share of self-employed persons was higher than 9810 in a German region in 1925, and 0 otherwise.
} 
various situations between East and West Germany (see Sect. 2), one may conjecture that this makes a case for managerial decision-making as well.

In fact, an increasing stream of finance research argues that cultural attributes are an important determinant of corporate finance decisions (see Aggarwal et al. (2016) for an overview and Nadler and Breuer (2019) for a systematic classification). For cash holdings, Chen et al. (2015) analyse the impact of culture on corporate cash holdings and argue that specific cultural attributes affect managers and their decisions. Based on an international sample and a subsample of only US firms, the authors develop their hypotheses regarding corporate cash holdings and observe that the national and regional levels of individualism have a significantly negative effect on firms' cash levels. Firms located in countries with an individualistic culture hold less cash than firms located in countries with a collectivistic culture. A high level of individualism is generally related to self-centredness and an overconfidence bias, which results in high optimism and overestimation of (own) abilities (Heine and Lehman 1995; Saad et al. 2015). In this context, Orlova (2020) observes that firms located in individualistic countries not only differ in cash holdings but also adjust cash holdings in another (more confidently) way than firms located in collectivistic countries. Further, Ramirez and Tadesse (2009) examine whether the national level of uncertainty avoidance (as another cultural attribute) affects corporate cash holdings. They observe that firms in countries with a high level of uncertainty avoidance hold more cash than their counterparts with low uncertainty levels. Notably, they include the level of sales generated in a foreign country to account for the level of firm multi-nationality and find that it weakens the cultural impact of uncertainty avoidance on cash holdings. Thus, firms with mainly domestic customers adhere more closely to cultural attributes. Chang and Noorbakhsh (2009) investigate the effect of culture on corporate cash holdings using besides uncertainty avoidance also long-term orientation and cultural masculinity as cultural attributes. Their results indicate that firms' cash holdings are positively correlated with uncertainty avoidance, masculinity, and long-term orientation.

These studies suggest that cultural attributes influence managerial decision-making measured by the level of corporate cash holdings. In our context, if the norms and values of the former GDR have a persistent impact on East German firm managers (implying different cultural attributes), differences in decision-making would be observed between East and West German firms as well. In other words, our main observation may be driven by differences in cultural attributes that influence managerial decision-making. If we assume that East and West German firm managers' cultural attributes are more collectivistic and individualistic, respectively, Chen et al.'s (2015) hypothesis would state that East German firms generally hold more cash than West German firms, and this is actually observed in our exploratory analysis.

Thus, higher cash holdings in East German firms are consistent with the hypothesis of different cultural attributes between East and West German managerial decision-making. However, we cannot definitively conclude that cultural attributes are the reason for this observation, as we only have the firms' locations but do not have any information about the managers' origin and their individual cultural attributes. In the following subsections, however, we present further evidence that corroborates our conjecture of differences in cultural attributes between East and West German managerial decision-making being the explanation for our main observation. 
Table 7 Cash holdings by size classes

\begin{tabular}{|c|c|c|c|c|}
\hline & (1) & (2) & (3) & (4) \\
\hline & Micro & Small & Medium & Large \\
\hline \multirow[t]{2}{*}{ East } & $0.030 * * *$ & $0.021 * * *$ & $0.012 * * *$ & -0.005 \\
\hline & $(0.007)$ & $(0.003)$ & $(0.004)$ & $(0.006)$ \\
\hline \multirow[t]{2}{*}{ Operating cash flow $_{t-1}$} & $0.071 * * *$ & $0.113^{* * *}$ & $0.077 * * *$ & $0.047 * * *$ \\
\hline & $(0.017)$ & $(0.007)$ & $(0.008)$ & $(0.010)$ \\
\hline \multirow[t]{2}{*}{ Cash flow volatility $_{t-1}$} & 0.042 & $0.045^{* *}$ & 0.032 & 0.012 \\
\hline & $(0.043)$ & $(0.018)$ & $(0.022)$ & $(0.026)$ \\
\hline \multirow[t]{2}{*}{ Inventory $_{t-1}$} & $-0.065^{* * *}$ & $-0.056^{* * *}$ & $-0.062 * * *$ & $-0.070 * * *$ \\
\hline & $(0.015)$ & $(0.006)$ & $(0.008)$ & $(0.012)$ \\
\hline \multirow[t]{2}{*}{ Net working capital t-1 $_{1}$} & $-0.071 * * *$ & $-0.070^{* * *} *$ & $-0.078^{* * *}$ & $-0.073 * * *$ \\
\hline & $(0.011)$ & $(0.004)$ & $(0.006)$ & $(0.008)$ \\
\hline \multirow[t]{2}{*}{ 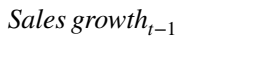 } & -0.003 & $-0.004 * *$ & -0.000 & 0.002 \\
\hline & $(0.006)$ & $(0.002)$ & $(0.003)$ & $(0.003)$ \\
\hline \multirow[t]{2}{*}{ Tangible assets $_{t-1}$} & $-0.158 * * *$ & $-0.189 * * *$ & $-0.181 * * *$ & $-0.151 * * *$ \\
\hline & $(0.016)$ & $(0.006)$ & $(0.009)$ & $(0.011)$ \\
\hline \multirow[t]{2}{*}{$\operatorname{Debt}_{t-1}$} & $-0.228 * * *$ & $-0.139 * * *$ & $-0.125^{* * *}$ & $-0.078 * * *$ \\
\hline & $(0.015)$ & $(0.006)$ & $(0.008)$ & $(0.009)$ \\
\hline \multirow[t]{2}{*}{ Total assets $_{t-1}$} & $-0.011^{* *}$ & $-0.007 * * *$ & $-0.007 * * *$ & $-0.006^{*}$ \\
\hline & $(0.005)$ & $(0.001)$ & $(0.002)$ & $(0.003)$ \\
\hline \multirow[t]{2}{*}{$\mathrm{Age}_{t}$} & 0.001 & $0.005^{* *}$ & $0.008 * * *$ & 0.003 \\
\hline & $(0.005)$ & $(0.002)$ & $(0.003)$ & $(0.003)$ \\
\hline \multirow[t]{2}{*}{ 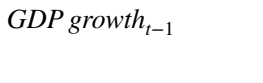 } & 0.163 & -0.018 & -0.014 & -0.016 \\
\hline & $(0.143)$ & $(0.042)$ & $(0.044)$ & $(0.041)$ \\
\hline IndustryFE & Yes & Yes & Yes & Yes \\
\hline YearFE & Yes & Yes & Yes & Yes \\
\hline$R^{2}$ & 0.308 & 0.292 & 0.258 & 0.179 \\
\hline$N$ & 5221 & 38,446 & 26,736 & 18,615 \\
\hline
\end{tabular}

This table reports random effects panel regression results with robust standard errors clustered at the firm level in parentheses. The baseline regression model is given by: Cash $_{i, t}=\alpha+\beta$ East $_{i}+\gamma X_{i, t}+D_{t}+D_{j}+\epsilon_{i, t}$. The first row indicates the respective size class subsample. Size classes are defined according to $\$ 267$ of the German Commercial Code. All specifications include year and industry fixed effects. We refer to Table 9 in the Appendix for details on the variable construction and to Table 10 in the Appendix for details on the size class definitions. Subscript $t-1$ means that the variable is lagged one period. $*, * *$ and $* * *$ indicate statistical significance at the $10 \%, 5 \%$ and $1 \%$ level

\subsection{Firm size differentiation}

If different cultural attributes are responsible for higher cash holdings in East German firms, we would expect this observation to vary with firm size. Large-sized firms typically base their corporate policy on group decisions which lead, according to Jansen et al. (2013), to a more diverse information set, implying less influence of an individual's cultural background. SMEs, on the other hand, involve fewer persons 
in the decision-making process; therefore, the cultural background of individual decision-makers is more prevalent. Consequently, managerial decision-making in SMEs tends to be more influenced by cultural attributes than managerial decisionmaking in large firms.

To examine whether this is the case for our data, we further classify firms into detailed size categories and analyse them separately. We use the $\$ 267$ classification of the German Commercial Code (see Table 10 in the Appendix for further details). For each firm size category (i.e. micro, small, medium, and large), we re-estimate Eq. (1). Columns (1) to (4) of Table 7 show that the East coefficient is highest for micro-sized firms and insignificant for large-sized firms, which is consistent with the hypothesis that different cultural attributes exist between East and West German managerial decision-making. While large-sized firms with diversified cultural attributes do not differ in managerial decision-making, smaller firms significantly differ in our proxy for managerial decision-making.

In this context, it is also important to note that all the studies mentioned above analyse large, listed firms that are likely to include more than one person in their decisionmaking processes and act in the global market. This might also imply that the potential effect of cultural attributes is diluted and actually underestimated by mainly focusing on large firms.

\subsection{Speed of adjustment}

If different cultural attributes are responsible for the higher cash holdings of East German firms, we would also expect the dynamic adjustment of cash to differ. In other words, we would expect a different behaviour if the target cash level is not met (i.e. excess cash or cash shortage). In fact, Orlova (2020) observes that firms located in individualistic countries tend to adjust cash slower in the case of a cash shortage and faster in the case of excess cash (compared with firms located in collectivist countries). As outlined above, this finding is also consistent with Chen et al.'s (2015) hypothesis. Another study by El Kalak et al. (2020) explicitly links managerial overconfidence with cash holdings' speed of adjustment and finds that overconfident firm managers adjust cash slower (faster) in the case of a cash shortage (excess cash).

As these studies document a relationship between cultural attributes and the dynamic adjustment of cash holdings, we expect to observe a similar pattern in our data. Therefore, we estimate a firm's target cash level and then analyse its speed of adjustment for a deviation from the target. According to Jiang and Lie (2016), the speed of adjustment (back to the target level) depends, among other aspects, on managers' willingness to make cash adjustments. Using Orlova's (2020) finding, we would consequently expect that East German firms adjust their level of cash for a deviation from the target differently than West German firms. We would expect to observe a lower speed of adjustment for East German firms in the case of excess cash, as there may be preferences for an excess liquidity buffer. For a cash shortage, on the other hand, we would expect to observe a higher speed of adjustment compared with their West German counterparts to reach the target cash level as quickly as possible. 
Table 8 Speed of adjustment

(1) (2) (3)

All SME Large

\begin{tabular}{|c|c|c|c|}
\hline \multicolumn{4}{|c|}{ Panel A: Excess cash: Cash $_{i, t}^{*}-$ Cash $_{i, t-1} \leq 40$ th Pct. } \\
\hline East $\times\left(\right.$ Cash $_{t}^{*}-$ Cash $\left._{t-1}\right)$ & $\begin{array}{l}-0.051 * * \\
(0.022)\end{array}$ & $\begin{array}{l}-0.057 * * \\
(0.023)\end{array}$ & $\begin{array}{l}0.024 \\
(0.074)\end{array}$ \\
\hline \multirow[t]{2}{*}{ Cash $_{t}^{*}-$ Cash $_{t-1}$} & $0.300 * * *$ & $0.311^{* * *}$ & $0.177 * * *$ \\
\hline & $(0.017)$ & $(0.018)$ & $(0.046)$ \\
\hline \multirow[t]{2}{*}{ East } & 0.002 & 0.002 & 0.004 \\
\hline & $(0.002)$ & $(0.003)$ & $(0.005)$ \\
\hline$R^{2}$ & 0.074 & 0.075 & 0.055 \\
\hline$N$ & 20,324 & 18,343 & 1980 \\
\hline \multicolumn{4}{|c|}{ Panel B: Cash shortage: Cash $_{i, t}^{*}-$ Cash $_{i, t-1} \geq 60$ th Pct. } \\
\hline \multirow{2}{*}{ East $\times\left(\right.$ Cash $_{t}^{*}-$ Cash $\left._{t-1}\right)$} & 0.008 & 0.016 & 0.044 \\
\hline & $(0.032)$ & $(0.034)$ & $(0.055)$ \\
\hline \multirow[t]{2}{*}{$\operatorname{Cash}_{t}^{*}-$ Cash $_{t-1}$} & $0.112 * * *$ & $0.107 * * *$ & 0.014 \\
\hline & $(0.021)$ & $(0.022)$ & $(0.037)$ \\
\hline \multirow[t]{2}{*}{ East } & 0.002 & 0.002 & -0.004 \\
\hline & $(0.003)$ & $(0.003)$ & $(0.005)$ \\
\hline$R^{2}$ & 0.004 & 0.004 & -0.000 \\
\hline$N$ & 20,324 & 18,344 & 1980 \\
\hline
\end{tabular}

This table reports the differences in speed of adjustment between East German firms and West German firms using the firm-characteristic matched sample. The regression model is given by:

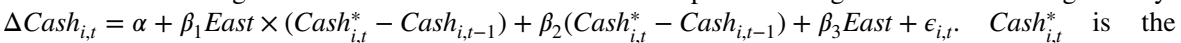
predicted cash ratio, when estimating the baseline model from Eq. (1) for West German firms in the matched samples. The first row of each panel indicates the sample used. We sort the sample according to $\operatorname{Cash}_{i, t}^{*}-\operatorname{Cash}_{i, t-1}$. If a firm $i$ 's Cash ${ }_{i, t}^{*}-$ Cash $_{i, t-1}$ lies within the bottom two quintiles ( $\leq 40$ th percentile), we include it in Panel A-the sample of excess cash. If it lies within the top two quintiles ( $\geq 60$ th percentile), we include it in Panel $\mathrm{B}$ - the sample of cash shortage. $*, * *$ and $* * *$ indicate statistical significance at the $10 \%, 5 \%$ and $1 \%$ level

As firm characteristics may considerably determine excess cash and speed of adjustment, we solely use the firm-characteristic matched sample (used in Sect. 4.1) for this exercise. Following Gao et al. (2013), we estimate the following partial adjustment model:

$$
\Delta \operatorname{Cash}_{i, t}=\alpha+\beta_{1} \operatorname{East} \times\left(\operatorname{Cash}_{i, t}^{*}-\operatorname{Cash}_{i, t-1}\right)+\beta_{2}\left(\operatorname{Cash}_{i, t}^{*}-\operatorname{Cash}_{i, t-1}\right)+\beta_{3} \operatorname{East}+\epsilon_{i, t},
$$

where $\Delta$ Cash $_{i, t}$ is the variation in cash from $t-1$ to $t$. Cash $_{i, t}^{*}$ is the firm's target cash ratio estimated by Eq. (1) using only the West German firms of the matched sample. Cash $_{i, t}^{*}-$ Cash $_{i, t-1}$ represents the firm's deviation from its target cash level, and $\beta_{2}$ measures how quickly firms adjust their cash holdings to their target level, that is, the speed of adjustment. Thus, $\beta_{1}$ measures whether the speed of adjustment differs between the East and West German firms. To differentiate between excess cash and cash shortages, we again follow Gao et al. (2013) and split the sample into two 
subsamples, wherein one consists of firms with Cash $_{i, t}^{*}-$ Cash $_{i, t-1}$ lying within the bottom two quintiles (i.e. $\leq 40$ th percentile) representing the case for excess cash. The other subsample consists of firms with $\operatorname{Cash}_{i, t}^{*}-$ Cash $_{i, t-1}$ lying within the top two quintiles (i.e. $\geq 60$ th percentile) representing the case for cash shortage. Panel A of Table 8 illustrates the results for excess cash holdings. The negative and statistically significant sign of the interaction term suggests that East German firms adapt their cash holdings more slowly to the target level in the case of excess cash. In other words, they tend to reduce excess cash more slowly than West German firms do. Importantly, this effect is significant only for SMEs. For a cash shortage (i.e. Panel B of Table 8), we observe that East German firms adapt their cash holdings at the same speed as West German firms do. While this result for a cash shortage is not in line with our expectation, it seems reasonable from an economic perspective that, given the importance of avoiding illiquidity, East and West German firms do not differ from each other in this case. Nonetheless, this suggests that East German firms differ not only in their cash levels but also in their dynamic adjustment of cash holdings in the case of excess cash.

\section{Conclusions}

In this study, we examine managerial decision-making through the lens of corporate cash holdings. Our exploratory analysis shows a significant difference in cash holdings between the East German and West German firms. These differences also have economic relevance, as our results suggest that cash holdings (relative to total assets) in East German firms are, on average, 15\% higher than that of West German firms. We test several reasonable, empirically validated hypotheses that stem from economic theory to help explain the observed differences in cash holdings. First, we exclude the possibility of structural differences in our sample by creating more homogenous subsamples. Second, we control for the possibility that East and West German firms have a different access to financing. Third, we control for historical differences in attitudes toward entrepreneurship. However, none of the tested hypotheses explain the observed differences in cash holdings.

Existing research holds the persistent norms and values of the former GDR accountable for observing differences in various situations between East and West Germany; this may hold true for the present study as well. However, because the underlying dataset of this study is only balance sheet data, such a conclusion is impossible, as we cannot exclude the existence of other unobserved determinants or underlying mechanisms. Nonetheless, we investigate this aspect in more detail and adapt existing research that documents a significant influence of cultural attributes on the level of cash holdings to our setting. The higher cash holdings in East German firms would indicate that cultural attributes between East and West German firm managers are different, implying that the norms and values of the former GDR are persistent. In this stream of literature, we present two additional analyses that investigate the differences in cash holdings based on different cultural attributes. While the results of both analyses (i.e. firm size differentiation and dynamic speed of adjustment) are consistent with the hypothesis of different cultural attributes 
between East and West German managerial decision-making, we acknowledge that our study has several limitations which, nonetheless, provide fruitful paths for future research.

First, as we lack information on the firm managers themselves, we cannot control for the case wherein West Germans migrate to East Germany to run a business, and vice versa. According to Wyrwich's (2010) survey, however, more than $85 \%$ of East German firms are owned by East Germans. It may further be worthwhile to combine managers' demographic data (i.e. gender, place of birth, level, and location of education) with accounting data to widen the knowledge base about differing cultural attributes of East and West German firm managers, respectively. Second, by drawing on Chen et al.'s (2015) and Orlova's (2020) hypotheses, we show that our observation is consistent with the hypothesis of different cultural attributes between East and West German managerial decision-making. However, existing research has also used several other cultural attributes to explain differences in corporate cash holdings - similar hypotheses can be developed with differences in, for instance, uncertainty avoidance, long-term orientation, or the level of trust. Third, we focus only on the level of corporate cash holdings as one aspect of managerial decision-making. While cash holdings represent an important corporate finance decision, future studies can also focus on other managerial decisions such as inventories, accounts payable, or retained earnings.

In conclusion, survey-based research in combination with accounting data is necessary to investigate the underlying mechanisms of managerial decision-making and whether (and if so, which) cultural attributes differ between East and West German firm managers. The survey data can indicate potential differences in cultural attributes, while the combined accounting data can allow conclusions regarding the effect on managerial decision-making. While this study contributes to the existing literature by extending research on the differences between East and West Germany and adding to the growing body of finance research on cultural attributes, further research that investigates the underlying mechanisms is of paramount importance. Understanding the determinants of differences in managerial decision-making can be valuable for transition economies worldwide that are experiencing a change in their socioeconomic framework. Such research adds an additional dimension to the literature that examines entrepreneurship, financial deepening, and consumption behaviour in transition economies (see Bursztyn and Cantoni 2016; McMillan and Woodruff 2002; Smallbone and Welter 2001; Wu et al. 2012).

\section{Appendix}




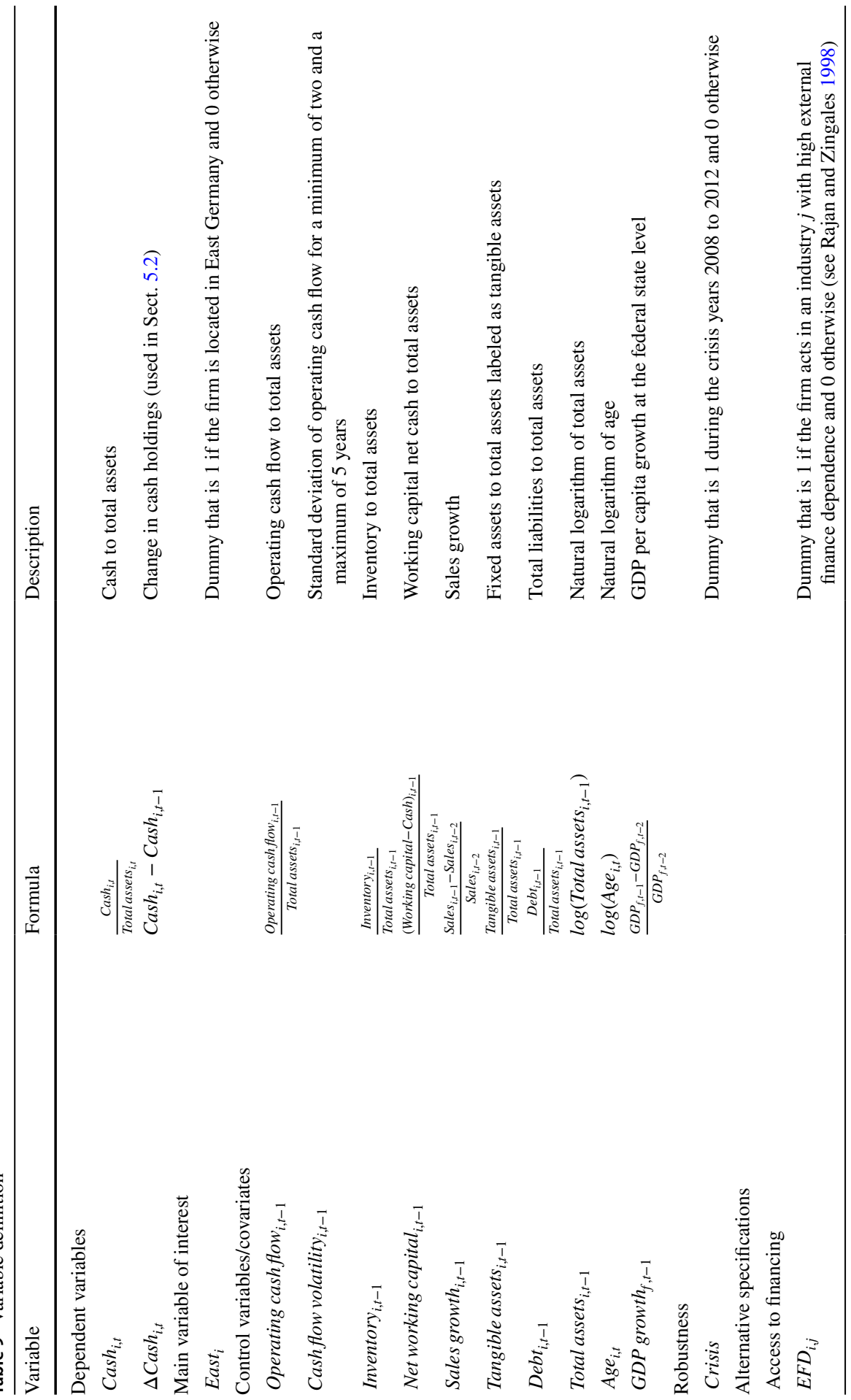




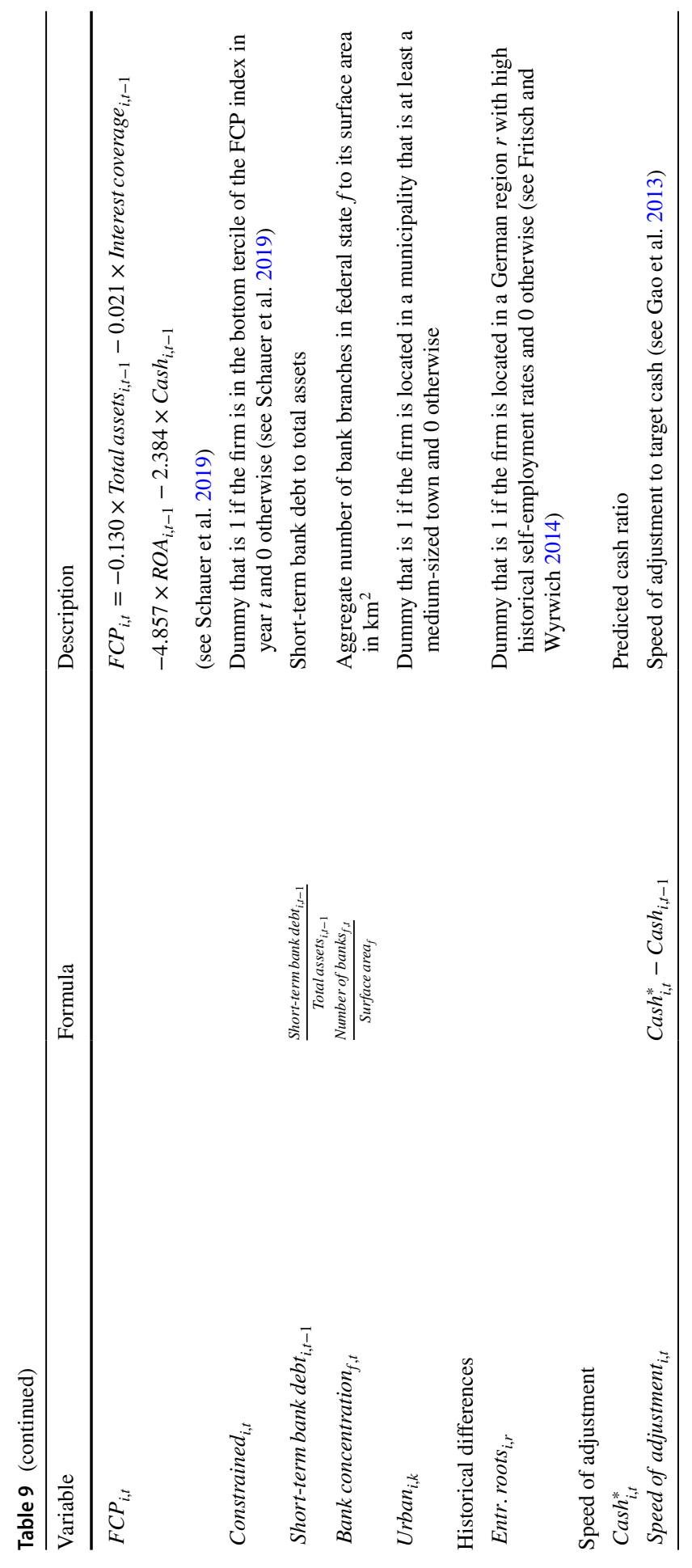


Table 10 Firm size definition

\begin{tabular}{llll}
\hline Size & Employees & Total assets $($ in $€)$ & Total sales (in $€$ ) \\
\hline Micro & $\mathrm{x} \leq 10$ & $\mathrm{x} \leq 350,000$ & $\mathrm{x} \leq 700,000$ \\
Small & $10<\mathrm{x} \leq 50$ & $350,000<\mathrm{x} \leq 484,000$ & $700,000<\mathrm{x} \leq 968,000$ \\
Medium & $50<\mathrm{x} \leq 250$ & $484,000<\mathrm{x} \leq 19.25$ Mio. & $968,000<\mathrm{x} \leq 38.5$ Mio. \\
Large & $>250$ & $>19.25$ Mio. & $>38.5$ Mio. \\
\hline
\end{tabular}

This table outlines the specification of firm size categories according to $\$ 267$ of the German Commercial Code: micro, small, medium and large-sized firms. At least two of the respective criteria have to be fulfilled to be assigned to one of the categories. Regarding the classification of SME, a firm is classified as SME if it either belongs to the micro, small, or medium-sized category

\section{Declarations}

Conflict of interest The authors have no relevant financial or non-financial interests to disclose.

Acknowledgements The authors are grateful to the two anonymous reviewers and the editor for their helpful and constructive comments. Furthermore, the authors also thank Emilia Garcia-Appendini, Jochen Lawrenz, Gunther Capelle-Blancard and the participants of the Finance Research Seminar at the University of Liechtenstein for their helpful suggestions. The authors thank Creditreform AG and Deutsche Bundesbank for data support. Julia Oberndorfer gratefully acknowledges the financial support from the dissertation grant provided by Creditreform Rating AG and Creditreform Wirtschaftsauskunftei Kubicki KG. Any remaining errors are the sole responsibility of the authors.

Funding Open access funding provided by University of Innsbruck and Medical University of Innsbruck.

Open Access This article is licensed under a Creative Commons Attribution 4.0 International License, which permits use, sharing, adaptation, distribution and reproduction in any medium or format, as long as you give appropriate credit to the original author(s) and the source, provide a link to the Creative Commons licence, and indicate if changes were made. The images or other third party material in this article are included in the article's Creative Commons licence, unless indicated otherwise in a credit line to the material. If material is not included in the article's Creative Commons licence and your intended use is not permitted by statutory regulation or exceeds the permitted use, you will need to obtain permission directly from the copyright holder. To view a copy of this licence, visit http://creativecommons.org/licenses/by/4.0/.

\section{References}

Acharya VV, Almeida H, Campello M (2007) Is cash negative debt? A hedging perspective on corporate financial policies. J Financ Intermed 16(4):515-554

Agarwal S, Hauswald R (2010) Distance and private information in lending. Rev Financ Stud 23(7):2757-2788

Aggarwal R, Faccio M, Guedhami O, Kwok CC (2016) Culture and finance: an introduction. J Corp Finance 41:466-474

Alesina A, Fuchs-Schündeln N (2007) Good-bye Lenin (or not?): the effect of communism on people's preferences. Am Econ Rev 97(4):1507-1528

Arena MP, Dewally M (2012) Firm location and corporate debt. J Bank Finance 36(4):1079-1092

Barro R (1991) Eastern germany's long haul. Wall Street J

Bates TW, Kahle KM, Stulz RM (2009) Why do U.S. firms hold so much more cash than they used to? J Finance 64(5):1985-2021

Bauernschuster S, Falck O, Gold R, Heblich S (2012) The shadows of the socialist past: lack of selfreliance hinders entrepreneurship. Eur J Polit Econ 28(4):485-497

Baumol WJ (1990) Entrepreneurship: productive, unproductive, and destructive. J Polit Econ 98(5):893-921 
Bedendo M, Garcia-Appendini E, Siming L (2020) Cultural preferences and firm financing choices. J Financ Quant Anal 55(3):897-930

Beirat des Bundeswirtschaftsministeriums (1991) Probleme der Privatisierung in den neuen Bundesländern. Studienreihe 73:1563-1582

Bernhardt K, Schwartz M (2015) 25 Jahre freier Bankenmarkt in Ostdeutschland-deutlicher Rückbau seit Wiedervereinigung. https:/www.kfw.de/KfW-Konzern/Newsroom/Aktuelles/NewsDetails_292032.html. Accessed 28 May 2021

Bertrand M, Duflo E, Mullainathan S (2004) How much should we trust differences-in-differences estimates. Quart J Econ 119(1):249-275

Brosig-Koch J, Helbach C, Ockenfels A, Weimann J (2011) Still different after all these years: solidarity behavior in East and West Germany. J Public Econ 95(11):1373-1376

Bursztyn L, Cantoni D (2016) A tear in the iron curtain: the impact of Western television on consumption behavior. Rev Econ Stat 98(1):25-41

Chang K, Noorbakhsh A (2009) Does national culture affect international corporate cash holdings? J Multinatl Financ Manag 19(5):323-342

Chen Y, Dou PY, Rhee SG, Truong C, Veeraraghavan M (2015) National culture and corporate cash holdings around the world. J Bank Finance 50:1-18

Daskalakis N, Jarvis R, Schizas E (2013) Financing practices and preferences for micro and small firms. J Small Bus Enterp Dev 20(1):80-101

Degryse H, Ongena S (2005) Distance, lending relationships, and competition. J Finance 60(1):231-266

Dittmar A, Mahrt-Smith J, Servaes H (2003) International corporate governance and corporate cash holdings. J Financ Quant Anal 38(1):111-133

Dornbusch R, Wolf HC (1994) East german economic reconstruction. In: The transition in eastern Europe, volume 1, country studies. University of Chicago Press, pp 155-190

Duchin R, Ozbas O, Sensoy BA (2010) Costly external finance, corporate investment, and the subprime mortgage credit crisis. J Financ Econ 97(3):418-435

El Kalak I, Goergen M, Guney Y (2020) CEO overconfidence and the speed of adjustment of cash holdings. In: Finance Working Paper 663, European Corporate Governance Institute

Fazzari SM, Hubbard RG, Petersen BC (1988) Financing constraints and corporate investment. Brook Pap Econ Act 1988(1):141-206

Foley CF, Hartzell JC, Titman S, Twite G (2007) Why do firms hold so much cash? A tax-based explanation. J Financ Econ 86(3):579-607

Friehe T, Mechtel M (2014) Conspicuous consumption and political regimes: evidence from East and West Germany. Eur Econ Rev 67:62-81

Fritsch M, Bublitz E, Sorgner A, Wyrwich M (2014) How much of a socialist legacy? The re-emergence of entrepreneurship in the East German transformation to a market economy. Small Bus Econ 43(2):427-446

Fritsch M, Kritikos AS, Sorgner A (2015) Why did self-employment increase so strongly in Germany? Entrep Reg Dev 27(5-6):307-333

Fritsch M, Wyrwich M (2014) The long persistence of regional levels of entrepreneurship: Germany, 1925-2005. Reg Stud 48(6):955-973

Fuchs-Schündeln N (2008) The response of household saving to the large shock of German reunification. Am Econ Rev 98(5):1798-1828

Fuchs-Schündeln N, Izem R (2012) Explaining the low labor productivity in East Germany-a spatial analysis. J Comp Econ 40(1):1-21

Gao H, Harford J, Li K (2013) Determinants of corporate cash policy: insights from private firms. J Financ Econ 109(3):623-639

Garcia-Appendini E (2018) Financial distress and competitors' investment. J Corp Finance 51:182-209

Garcia-Appendini E, Montoriol-Garriga J (2013) Firms as liquidity providers: evidence from the 20072008 financial crisis. J Financ Econ 109(1):272-291

González VM, González F (2008) Influence of bank concentration and institutions on capital structure: new international evidence. J Corp Finance 14(4):363-375

Heine SJ, Lehman DR (1995) Cultural variation in unrealistic optimism: does the west feel more vulnerable than the East? J Pers Soc Psychol 4(68):595-607

Heineck G, Süssmuth B (2013) A different look at Lenin's legacy: social capital and risk taking in the two Germanies. J Comp Econ 41(3):789-803

Imbens GW, Wooldridge JM (2009) Recent developments in the econometrics of program evaluation. J Econ Lit 47(1):5-86 
Jansen RJ, Curşeu PL, Vermeulen PA, Geurts JL, Gibcus P (2013) Information processing and strategic decision-making in small and medium-sized enterprises: The role of human and social capital in attaining decision effectiveness. Int Small Bus J 31(2):192-216

Jensen MC, Meckling WH (1976) Theory of the firm: managerial behavior, agency costs and ownership structure. J Financ Econ 3(4):305-360

Jiang Z, Lie E (2016) Cash holding adjustments and managerial entrenchment. J Corp Finance 36:190-205

Kaplan SN, Zingales L (1997) Do investment-cash flow sensitivities provide useful measures of financing constraints? Quart J Econ 112(1):169-215

Keefe MO, Yaghoubi M (2016) The influence of cash flow volatility on capital structure and the use of debt of different maturities. J Corp Finance 38:18-36

Lehmann E, Neuberger D, Räthke S (2004) Lending to small and medium-sized firms: is there an EastWest gap in Germany? Small Bus Econ 23(1):23-39

Lins KV, Servaes H, Tufano P (2010) What drives corporate liquidity? An international survey of cash holdings and lines of credit. J Financ Econ 98(1):160-176

McMillan J, Woodruff C (2002) The central role of entrepreneurs in transition economies. J Econ Perspect 16(3):153-170

Nadler C, Breuer W (2019) Cultural finance as a research field: an evaluative survey. J Bus Econ 89:191-220

Necker S, Voskort A (2014) Politics and parents-intergenerational transmission of values after a regime shift. Eur J Polit Econ 36:177-194

Opler T, Pinkowitz L, Stulz RM, Williamson R (1999) The determinants and implications of corporate cash holdings in China. J Financ Econ 52:3-46

Orlova SV (2020) Cultural and macroeconomic determinants of cash holdings management. J Int Financ Manag Acc 31(3):270-294

Pettit RR, Singer RF (1985) Small business finance: a research agenda. Financ Manag 14(3):47-60

Phan HV, Nguyen NH, Nguyen HT, Hegde S (2019) Policy uncertainty and firm cash holdings. J Bus Res 95:71-82

Psillaki M (1995) Credit rationing and small and medium sized firms: a tentative of linkage. Revue Internationale PME 8(3/4):67-90

Rainer H, Siedler T (2009) Does democracy foster trust? J Comp Econ 37(2):251-269

Rajan RG, Zingales L (1998) Financial dependence and growth. Am Econ Rev 88(3):559-586

Ramírez A, Tadesse S (2009) Corporate cash holdings, uncertainty avoidance, and the multinationality of firms. Int Bus Rev 18(4):387-403

Runst P (2013) Post-socialist culture and entrepreneurship. Am J Econ Sociol 72(3):593-626

Saad G, Cleveland M, Ho L (2015) Individualism-collectivism and the quantity versus quality dimensions of individual and group creative performance. J Bus Res 68(3):578-586

Schauer C, Elsas R, Breitkopf N (2019) A new measure of financial constraints applicable to private and public firms. J Bank Finance 101:270-295

Smallbone D, Welter F (2001) The distinctiveness of entrepreneurship in transition economies. Small Bus Econ 16(4):249-262

Snower DJ, Merkl C (2006) The caring hand that cripples: the East German labor market after reunification. Am Econ Rev 96(2):375-382

Uhlig H (2006) Regional labor markets, network externalities and migration: the case of German reunification. Am Econ Rev 96(2):383-387

Uhlig H (2008) The slow decline of East Germany. J Comp Econ 36(4):517-541

Weidemann JF (2019) A state-of-the-art review of corporate cash holding research. J Bus Econ 88:765-797

Wu W, Rui OM, Wu C (2012) Trade credit, cash holdings, and financial deepening: evidence from a transitional economy. J Bank Finance 36(11):2868-2883

Wyrwich M (2010) Assessing the role of strategy and socioeconomic heritage for rapidly growing firms: evidence from Germany. Int J Entrep Ventur 1(3):245-263

Wyrwich M (2013) Can socioeconomic heritage produce a lost generation with regard to entrepreneurship? J Bus Ventur 28(5):667-682

Wyrwich M (2015) Entrepreneurship and the intergenerational transmission of values. Small Bus Econ 45(1):191-213

Publisher's Note Springer Nature remains neutral with regard to jurisdictional claims in published maps and institutional affiliations. 